\title{
Flotation Frothers: Review of Their Classifications, Properties and Preparation
}

\author{
Hamid Khoshdast* and Abbas Sam
}

Department of Mining Engineering, Faculty of Engineering, Shahid Bahonar University, 76169133, Kerman, Iran

\begin{abstract}
The importance of frothers in flotation is widely acknowledged, particularly in terms of their role with respect to bubble size, and the stability and mobility of the froth phase. These factors play a significant role in the kinetic viability of the process, and the overall recovery and the grade that can be achieved from a flotation cell or circuit. About 60 years ago, Wrobel [1] presented a comprehensive review of flotation frothers, their action, properties and structures. However, during recent six decades flotation reagent technology has undergone considerable evolutions and innovations. The aim of the present review is to provide an updated, comprehensive database comprising recent developments in flotation frother technology as well as some historical aspects. Different types of flotation frothers are discussed regarding to their classifications, properties, and preparation methods. New classification schemes have been suggested in parallel with introducing new characterization criteria. New classes of frothers are actually conventional frothers modified by incorporating certain functional "group" or "atoms" into their molecular structure. Like particle surface modifiers, frothers are also influenced by biotechnology, leading to introducing a new class of frothers named as "biofrothers".
\end{abstract}

Keywords: Flotation frother, Classification, Properties, Preparation.

\section{INTRODUCTION}

When two bubbles come in contact with each other, the liquid film between them thins and breaks, causing bubbles to coalesce. When coalescence of bubbles formed in a liquid (or released into it) does not take place in fractions of seconds, the bubbles rise to the surface and aggregate, forming a foam or a froth [2]. Two definitions can be derived from the literature to distinguish between foam and froth, as follow:

- The imperfectly drained liquid-bubble systems, generally unstable, are called foam, while the more persistent, better drained bubble systems are referred to as froths [2]. In a review on foaming, Kitchener and Cooper [3] provided a sequence of photographs showing a gradual transition of structure from that of non-drained "foam" with spherical bubbles to a relatively well-drained "froth" with polyhedral bubbles, separated by very thin lamellae. Fig. (1) shows this structural transition from foam to froth. This description is frequently used in colloidal sciences.

- Foam comprises a two-phase system of air and liquid, whereas froth contains dispersed solid particles, so that the structure consists of three phases of air, liquid and solid and when broken down gives a two-phase system (aqueous solution and finely divided particles) [4]. Such a distinction is commonly used in coal and mineral flotation.

Foams and froths are of considerable practical importance not only in froth flotation of minerals or in adsorptive

*Address correspondence to this author at the Department of Mining Engineering, Faculty of Engineering, Shahid Bahonar University, 76169133, Kerman, Iran; Tel: +98 91353259 04; Fax: +98 34121210 03; E-mail: khoshdast_hamid@yahoo.com bubble-separation techniques applied to wastewater treatment, deinking of paper in paper recycling and processing of oil sands but also in the food industry $[2,5]$.

Despite the area of application, there is one known fact that pure liquids of low viscosity do not foam or froth and neither do the solutions containing hydrophilic solutes. Here is the area where a group of surface-active agents come into account which is so called "frothers", supporting the requirements in regard to forming foams and froths. After over a century from the appearance of froth flotation, the technology of flotation reagents has undergone significant mutations as well as other physical and mechanical aspects of this process. In parallel, several investigators have always tried to present comprehensive reviews to provide updated databases of such developments. Since 1953s when Wrobel [1] presented a comprehensive review of flotation frothers, their action, properties and structures, a large body of literature on frother studies has risen by different workers. In this regard, the present review has been prepared to provide an updated database including recent advances in flotation frother technology in terms of their classifications, characteristics, and preparation methods.

\section{FROTHERS}

Without reagents there would be no flotation, and without flotation the mining industry, as we know it today, would not exist. Flotation is the only processing method in which three phases of air, liquid, and solid are involved, simultaneously. Therefore, the reagent schemes are those resulting in reliable conditions of mentioned phases. In this regard, flotation reagents include collectors and surface modifiers, frothers, and pH-regulators controlling physical and chemical conditions of solid, air, and liquid phases, respectively. The 


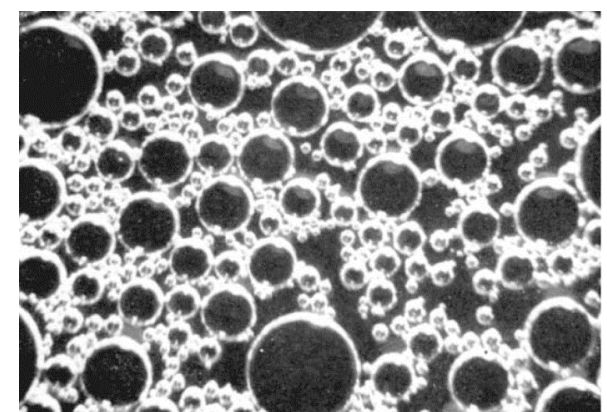

$$
\text { (a) }
$$

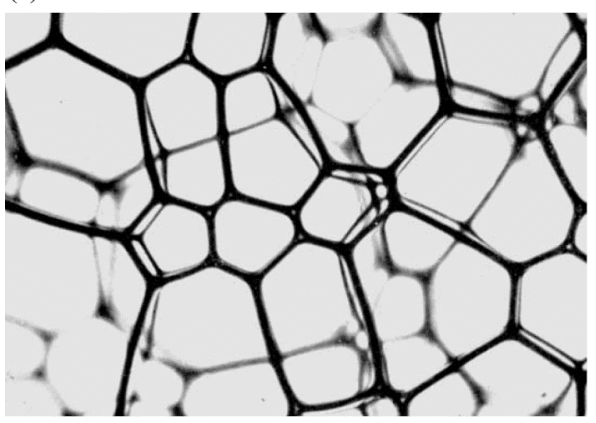

(c)

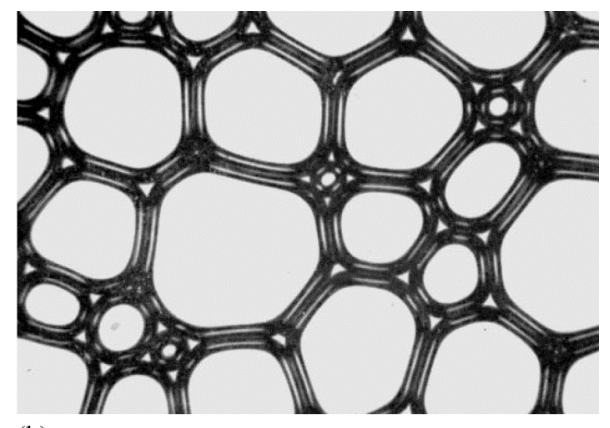

(b)

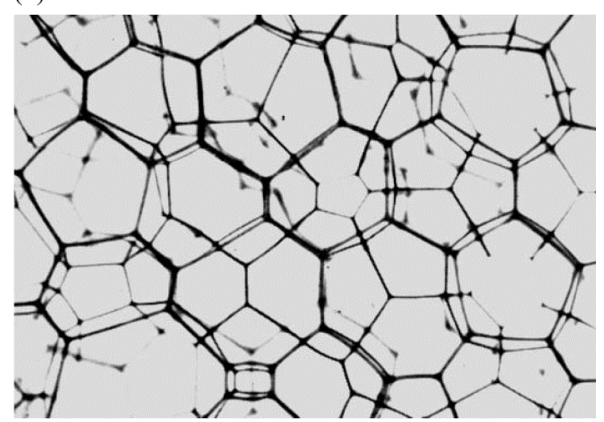

(d)

Fig. (1). Photomicrographs showing foam to froth transition: (a) a non-drained spherical bubble "foam"; (b) a partially-drained foam, showing distortion of bubbles; (c) after further drainage, the lamellae and Plateau borders continue to thin; and (d) a well-drained froth, showing polyhedral cells and very thin Plateau borders [3].

importance of frothers in flotation is widely acknowledged, particularly in terms of their role with respect to bubble size, and the stability and mobility of the froth phase. These factors play a significant role in the kinetic viability of the process, and the overall recovery and the grade that can be achieved from a flotation cell or circuit [6].

Frothers are heteropolar surface-active compounds containing a polar group and a hydrocarbon radical, capable of adsorbing in the air-water interface. As shown in Fig. (2), the frother molecules are arranged at the air-water interface such that the hydrophilic or polar groups are oriented into the water phase and the hydrophobic or non-polar hydrocarbon chain in the air phase. In fact, the frother creates conditions for froth formation. As fallowed, the flotation froth is a three-phase system. The frother concentrates at the interface of water and air bubbles, forming an envelope around the bubbles, which prevents them from colliding or touching. Frothers also lower the surface tension of the water. The forces created around the air bubble in the presence of a frother prevent the bubbles from collapsing [7]. Two edited books frothing in flotation volume I and II give a comprehensive information on frother mechanisms and frothing practices $[8,9]$.

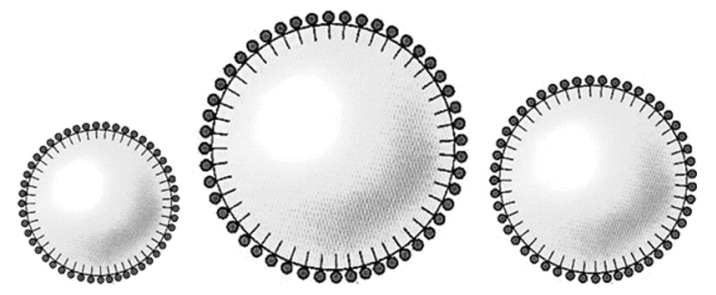

Fig. (2). Orientation of the frother molecules in the surface of bubbles [10].

\section{CLASSIFICATION OF FROTHERS}

In the literature, there are several different classifications of frothers depending on their properties and behaviors in solution and pulp. Four classification methods commonly used are based on pH-sensitivity, solubility, frothing/ collecting ability, and selectivity/frothing-power relationship. The other classifications are tentative because some of the compounds used as frother have been or still are proprietary products and their structures are seldom disclosed, e.g. $\mathrm{F} \#$ and $\mathrm{T} \#$ frothers.

\section{1. pH-Sensitivity Based Classification}

Dudenkov and Galikov [11] have classified the frothers depending on the frother behavior at different $\mathrm{pH}$ values. This classification is shown in Table $\mathbf{1}$.

Table 1. Classification of Frothers Based on Their pHSensitivity

\begin{tabular}{|c|c|c|}
\hline Acidic & Neutral & Basic \\
\hline \hline Phenols & Aliphatic alcohols & Pyridine base \\
$\begin{array}{c}\text { Alkyl sul- } \\
\text { fonates }\end{array}$ & Cyclic alcohols and Natural oils & \\
& Alkoxy paraffins & \\
& Polypropylene glycol ethers & \\
& Polyglycol ethers & \\
& Polyglycol glycerol ethers & \\
\hline
\end{tabular}

\subsubsection{Acidic Frothers}

These frothers perform well only in acidic pHs. In an alkaline medium, their frothing properties are reduced. The 
acidic frothers have been used extensively until the 1960s. Their application has been diminishing because of environmental considerations. The two following groups of these frothers have been used in mineral processing plants: phenols and alkyl sulfonates [7].

\section{A) Phenols}

Phenols are also known as aromatic alcohols. The general formulas of the main members of these frothers are shown in Fig. (3). These frothers are obtained as a byproduct during gasification of coal tar and/or distillation of crude oil. The main problem associated with the use of phenol as a frother is its variable composition, which depends on the source from which the frother is derived. For example, phenol can be made from the partial oxidation of benzene, the reduction of benzoic acid, by the cumene process, or by the RaschigHooker process. It can also be found as a product of coal oxidation [12]. Naphthalene (naphthalin) is the most abundant single component of coal tar. From the 1960s to the 1990 s, significant amounts of naphthalene were also produced from heavy petroleum fractions during petroleum refining, but today petroleum-derived naphthalene represents only a minor component of naphthalene production. Although the composition of coal tar varies with the coal from which it is produced, typical coal tar is about 10 percent naphthalene by weight. In industrial practice, distillation of coal tar yields oil containing about 50 percent naphthalene, along with a variety of other aromatic compounds. This oil, after being washed with aqueous sodium hydroxide to remove acidic components, undergoes fractional distillation to isolate naphthalene. The crude naphthalene resulting from this process is 95 percent naphthalene by weight, often referred to as $78^{\circ} \mathrm{C}$ (melting point). The chief impurities are the sulfur-containing aromatic compound benzothiophene $(<2$ percent), indane $(0.2$ percent $)$, indene $(<2$ percent $)$, and methylnaphthalene $(<2$ percent). Petroleum-derived naphthalene is usually purer than that derived from coal tar. Where required, crude naphthalene can be further purified by recrystallization from any of a variety of solvents, resulting in 99 percent naphthalene by weight, referred to as $80^{\circ} \mathrm{C}$ (melting point) $[12,13]$.<smiles>Cc1ccccc1O</smiles>

ortho-Cresol<smiles>Oc1ccccc1</smiles>

Phenol

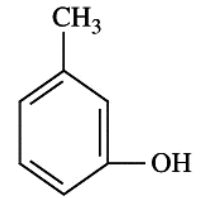

meta-Cresol

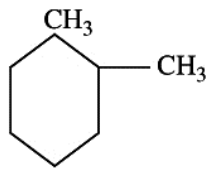

Toluol<smiles>Cc1ccc(O)cc1</smiles>

para-Cresol

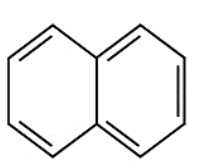

Naphthalin
Fig. (3). Chemical structures of the main components of phenols [7].

Toluol (toluene) is another member of phenol frothers which occurs naturally at low levels in crude oil and is usu- ally produced in the processes of making gasoline via a catalytic reformer, in an ethylene cracker or making coke from coal. Final separation (either via distillation or solvent extraction) takes place in a BTX plant [12]. Xylenol also belongs to the aromatic alcoholic type frothers. This frother is a mixture of xylenol isomers. The chemical structures of xylenol isomers are shown in Fig. (4). The methyl groups can assume six different arrangements. The 3,4- position is the most abundant. Xylenols are obtained from coal by distillation. Similar to phenols, these frothers also have a variable composition. Phenols and xylenols can be added to tall oil fatty acids to improve selectivity as well as power [7].

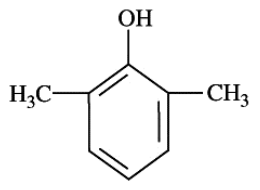

2,6-dimethylphenol (2,6-xylenol)<smiles>Cc1cccc(O)c1C</smiles>

2,3-dimethylphenol (2,3-xylenol)<smiles>Cc1ccc(C)c(O)c1</smiles>

2,5-dimethylphenol (2,5-xylenol)<smiles>Cc1ccc(O)cc1C</smiles>

3,4-dimethylphenol (3,4-xylenol)<smiles>Cc1ccc(O)c(C)c1</smiles>

2,4-dimethylphenol

(2,4-xylenol)

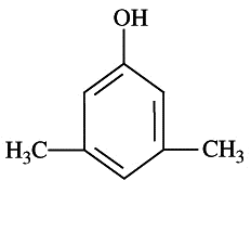

3,5-dimethylphenol (3,5-xylenol)
Fig. (4). Chemical structures of xylenol isomers [12].

The most typical frother from phenol type frothers is cresylic acid (actually not an acid), consisting of a mixture of phenols containing varying amount of the three isomers of cresol (see Fig. 3), xylenols, and other high-boiling fractions. Cresols are acidulation products of toloul. The three isomers of cresol have strong collecting properties. Their popularity declined when acid circuit mills went out of fashion; however, they are still popular in coal flotation because of their availability from coking ovens. The froths produced by cresylic acids are generally similar in structure to those of pine oil, but of a somewhat larger bubble size. An increase in frother dosage decreases froth volume and produces a tendency to effervesce. The lower boiling fractions produce a more fragile froth and are somewhat more selective [7, 14]. Typical specifications for flotation grade cresylic acids were distillation range $190-235^{\circ} \mathrm{C}$, with no more than 2 percent below $190^{\circ} \mathrm{C}$, no less than 75 percent distilling below $235^{\circ} \mathrm{C}$, density of 1.01 to $1.04 \mathrm{~g} / \mathrm{ml}$, and $1.7 \mathrm{~g} / 1$ water solubility. Today's commercial grade has not less than 50 percent distilling over $204^{\circ} \mathrm{C}$. If it boils below $204^{\circ} \mathrm{C}$ it is called cresol. A typical commercial cut boils between $220-250^{\circ} \mathrm{C}$, and has as typical compositions meta, para-cresols $0-1$ percent, 2,4and 2,5-xylenols $0-3$ percent, 2,3- and 3,5-xylenols $10-20$ percent, 3,4-xylenols $20-30$ percent, and $\mathrm{C}_{9}$ phenols 50-60 percent [14].

Froth characteristics and collector properties of cresylic acids are very dependent on the $m$-cresol and phenol content, 
Table 2. Physical and Chemical Properties of Phenols [7,12,14]

\begin{tabular}{|c|c|c|c|c|c|c|c|}
\hline & Formula & $\begin{array}{l}\text { Mw, } \\
\text { g/mol }\end{array}$ & $\begin{array}{c}\text { Density, } \\
\text { g/ml }\end{array}$ & $\begin{array}{c}\text { Solubility, } \\
\text { g/l }\end{array}$ & $\begin{array}{l}\text { Freezing } \\
\text { Point, }{ }^{\circ} \mathrm{C}\end{array}$ & $\begin{array}{c}\text { Boiling } \\
\text { Point, }{ }^{\circ} \mathrm{C}\end{array}$ & State \\
\hline Phenol & $\mathrm{C}_{6} \mathrm{H}_{5} \mathrm{OH}$ & 94.11 & 1.07 & 83 & 40.5 & 181.7 & white crystalline solid \\
\hline Toluol & $\mathrm{C}_{6} \mathrm{H}_{5} \mathrm{CH}_{3}$ & 92.14 & 0.87 & 0.47 & -93 & 110.6 & colorless liquid \\
\hline Naphthalene & $\mathrm{C}_{10} \mathrm{H}_{8}$ & 128.17 & 1.14 & 0.03 & 80.55 & 218 & white solid crystals \\
\hline \multicolumn{8}{|c|}{ Xylenols ( dimethylphenols): } \\
\hline 2,6-xylenol & $\left(\mathrm{CH}_{3}\right)_{2} \mathrm{C}_{6} \mathrm{H}_{3} \mathrm{OH}$ & 122.16 & & & $43-45$ & 203 & \\
\hline 2,5-xylenol & $\left(\mathrm{CH}_{3}\right)_{2} \mathrm{C}_{6} \mathrm{H}_{3} \mathrm{OH}$ & 122.16 & 0.971 & & $63-65$ & 212 & \\
\hline 2,4-xylenol & $\left(\mathrm{CH}_{3}\right)_{2} \mathrm{C}_{6} \mathrm{H}_{3} \mathrm{OH}$ & 122.16 & 1.011 & & $22-23$ & $211-212$ & \\
\hline 2,3-xylenol & $\left(\mathrm{CH}_{3}\right)_{2} \mathrm{C}_{6} \mathrm{H}_{3} \mathrm{OH}$ & 122.16 & & & $70-73$ & 217 & \\
\hline 3,4-xylenol & $\left(\mathrm{CH}_{3}\right)_{2} \mathrm{C}_{6} \mathrm{H}_{3} \mathrm{OH}$ & 122.16 & & & $62-68$ & 227 & \\
\hline 3,5-xylenol & $\left(\mathrm{CH}_{3}\right)_{2} \mathrm{C}_{6} \mathrm{H}_{3} \mathrm{OH}$ & 122.16 & & & $61-64$ & 222 & \\
\hline \multicolumn{8}{|l|}{ Cresols: } \\
\hline$o$-cresol & $\mathrm{CH}_{3} \mathrm{C}_{6} \mathrm{H}_{4} \mathrm{OH}$ & 108.14 & 1.05 & 25 & 29.8 & 191 & colorless crystals \\
\hline$m$-cresol & $\mathrm{CH}_{3} \mathrm{C}_{6} \mathrm{H}_{4} \mathrm{OH}$ & 108.14 & 1.03 & 24 & 11.8 & 202 & thicker liquid \\
\hline$p$-cresol & $\mathrm{CH}_{3} \mathrm{C}_{6} \mathrm{H}_{4} \mathrm{OH}$ & 108.14 & 1.02 & 19 & 35.5 & 201.9 & greasy-looking solid \\
\hline
\end{tabular}

so specifications of cresylic acid purchases should be rigorous if froth control problems are able to be avoided in the concentrator. The purer cresylic acids are ruptured to give a more fragile froth and to require a stronger collector for good flotation. Impure cresylic acids contain pyridines and sulfur impurities, which were much sought after 70 to 90 years ago in flotation mills when the frother was also employed as a collector, but in conjunction with selective collectors these cresylic acids can give process control problems. Today, a mixture of tall oil fatty acids and cresol has been successfully used for flotation of spodumene and phenacite [14]. Table 2 shows some physical and chemical properties of phenol frothers.

\section{B) Alkyl Sulfonates}

Alkyl (alkylaryl) sulfonate can be described as an anionic frother with a structure that is composed of an aromatic hydrocarbon and aliphatic radical. In spite of the fact that these frothers have good frothing properties, their application was limited, likely because most alkylaryl sulfonate frothers contain traces of sulfur, which interfere with flotation [7]. Fig. (5) shows the chemical formula of these frothers.

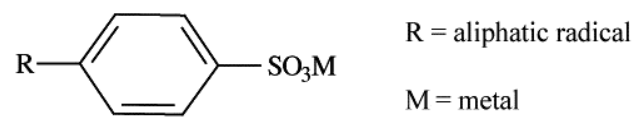

Fig. (5). Chemical structure of alkylaryl sulfonates [7].

\subsubsection{Basic Frothers}

These frothers are represented by pyridine and homologs, recovered as byproducts from coal tar distillation. They are used for flotation of base-metal ores. In Europe, a similar product was used to produce a collector applied in the flota- tion of oxide lead minerals. The following two structures are used as frothers [7]. Fig. (6) shows the chemical formulas of these frothers.<smiles>[O-]c1cc[nH][14cH]1</smiles>

Pyridine oxychloride<smiles>O=S1(=O)ON1c1ccccc1</smiles>

Pyridine sulfotrioxide
Fig. (6). Chemical structures of two basic frothers used commercially [7].

\subsubsection{Neutral Frothers}

This is the most important group of frothers widely used in flotation of base-metal ores, oxidic minerals and industrial minerals. They are functional in both acidic and alkaline pulps. These frothers are divided into six sub-groups, with wide differences in chemical composition.

\section{A) Aliphatic Alcohols}

These frothers are mixtures of alcohols containing 6-8 carbon atoms. They were at one time marketed by DuPont and still are by Cyanamid, as tailored frothers for specific ore types. The best-known frother from this group is methyl isobutyl carbinol (MIBC or 4-methyl-2-pentanol) and 2-ethyl hexanol (4-heptanol). Cyanamid Company produces MIBC under the trade name AF70 [7,14]. Fig. (7) shows the extended formulas of aliphatic alcohol frothers. 
<smiles>CC(C)CC(C)O</smiles>

Methyl isobutyl carbinol (MIBC)<smiles>CC(C)C(=O)OCC(C)(C)C(O)C(C)C</smiles>

2,2,4-trimethylpentanediol 1,3-monoisobutyrate (TEXANOL)<smiles>CCCO</smiles>

$n$-propanol<smiles>CCCCCCO</smiles>

$n$-hexanol<smiles>CCCCCCCCO</smiles>

n-octanol<smiles>CCCCO</smiles>

n-butanol<smiles>CCC(C)O</smiles>

2-butanol<smiles>CCCC(CC)CO</smiles>

2-ethyl hexanol (4-heptanol)<smiles>CC(=O)OCC(C)(C)O</smiles>

Diacetone alcohol<smiles>CCCCCO</smiles>

$n$-pentanol

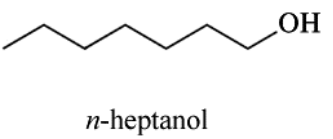

$t$-butanol<smiles>CC1(O)CC1</smiles><smiles>CC(C)CCO</smiles>

Isoamyl alcohol

Fig. (7). Chemical structures of aliphatic alcohols $[7,14,15]$.

The properties of aliphatic alcohol frothers are shown in Table 3. Propanol is manufactured commercially by catalytic hydrogenation of propionaldehyde as follows:

$$
\begin{aligned}
& \mathrm{H}_{2} \mathrm{C}=\mathrm{CH}_{2}+\mathrm{CO}+\mathrm{H}_{2} \rightarrow \mathrm{CH}_{3} \mathrm{CH}_{2} \mathrm{CH}=\mathrm{O} \\
& \mathrm{CH}_{3} \mathrm{CH}_{2} \mathrm{CH}=\mathrm{O}+\mathrm{H}_{2} \rightarrow \mathrm{CH}_{3} \mathrm{CH}_{2} \mathrm{CH}_{2} \mathrm{OH}
\end{aligned}
$$

Butanol is produced industrially from the petrochemical feedstock propylene. Propylene is hydroformylated to butyraldehyde (i.e. Oxo process) in the presence of a rhodium-based homogeneous catalyst similar to Wilkinson's catalyst. The butyraldehyde is then hydrogenated to produce $n$-butanol. 2-butanol is produced by the hydration of 1 butene or 2-butene:

$\mathrm{H}_{3} \mathrm{CHC}=\mathrm{CHCH}_{3}+\mathrm{H}_{2} \mathrm{O} \rightarrow \mathrm{CH}_{3} \mathrm{CHOH}\left(\mathrm{CH}_{2}\right) \mathrm{CH}_{3}$

Sulfuric acid is used as a catalyst for this conversion. $t$ Butanol is derived from isobutene as a co-product of propylene oxide production. It can also be produced by the catalytic hydration of isobutylene [12].

Pentanol can be prepared by fractional distillation of fusel oil. Heavier alcohols are produced industrially by the oligomerization of ethylene using triethylaluminium followed by oxidation of the alkylaluminium products. For example, an idealized synthesis for hexanol and octanol are shown:

Hexanol:

$$
\begin{aligned}
& \mathrm{Al}\left(\mathrm{C}_{2} \mathrm{H}_{5}\right)_{3}+6 \mathrm{C}_{2} \mathrm{H}_{4} \rightarrow \mathrm{Al}\left(\mathrm{C}_{6} \mathrm{H}_{13}\right)_{3} \\
& \mathrm{Al}\left(\mathrm{C}_{6} \mathrm{H}_{13}\right)_{3}+1 \frac{1}{2} \mathrm{O}_{2}+3 \mathrm{H}_{2} \mathrm{O} \rightarrow 3 \mathrm{CH}_{3}\left(\mathrm{CH}_{2}\right)_{5} \mathrm{OH}+\mathrm{Al}(\mathrm{OH})_{3} \ldots
\end{aligned}
$$

Octanol:

$\mathrm{Al}\left(\mathrm{C}_{2} \mathrm{H}_{5}\right)_{3}+9 \mathrm{C}_{2} \mathrm{H}_{4} \rightarrow \mathrm{Al}\left(\mathrm{C}_{8} \mathrm{H}_{17}\right)_{3}$

$\mathrm{Al}\left(\mathrm{C}_{8} \mathrm{H}_{17}\right)_{3}+1 \frac{1}{2} \mathrm{O}_{2}+3 \mathrm{H}_{2} \mathrm{O} \rightarrow 3 \mathrm{CH}_{3}\left(\mathrm{CH}_{2}\right)_{7} \mathrm{OH}+\mathrm{Al}(\mathrm{OH})_{3}$

The process generates a range of alcohols that are separated by distillation $[12,16]$.

Aliphatic alcohol frothers are also used as mixtures of different carbon lengths and as a mixture of hydrocarbon oils. The following mixtures are common in mineral flotation $[7,14]$ :

- Mixture of $\mathrm{C}_{6}-\mathrm{C}_{9}$ alcohols: a specific gravity of 0.856 , viscosity of $5 \mathrm{cps}$, low water solubility, and flash point of $52^{\circ} \mathrm{C}$. These frothers are regarded as highly selective.

- Mixtures of $\mathrm{C}_{4}-\mathrm{C}_{7}$ alcohols and hydrocarbon oil: an amber liquid with a specific gravity of 0.82 , viscosity of 4.5 cps, water solubility of $5 \mathrm{~g} / \mathrm{l}$, and flash point of $44^{\circ} \mathrm{C}$. These frothers are usually used during coppermolybdenum or molybdenum flotation, and are also recommended for flotation of minerals such as talc, graphite, sulfur and coal. Mixed $\mathrm{C}_{4}$ to $\mathrm{C}_{7}$ alcohols produce a livelier froth than MIBC.

- Mixtures of $\mathrm{C}_{5}-\mathrm{C}_{8}$ carbon alcohols: a specific gravity of $0.81-0.83$, viscosity of $6.9 \mathrm{cps}$, water solubility of $10 \mathrm{~g} / \mathrm{l}$, 
Table 3. Physical and Chemical Properties of Aliphatic Frothers [6,7,12,15,17-19]

\begin{tabular}{|c|c|c|c|c|c|c|c|}
\hline & Formula & $\begin{array}{l}\text { Mw, } \\
\text { g/mol }\end{array}$ & $\begin{array}{l}\text { Density, } \\
\text { g/ml }\end{array}$ & $\begin{array}{l}\text { Solubility, } \\
\text { g/l }\end{array}$ & $\begin{array}{l}\text { Freezing } \\
\text { Point, }{ }^{\circ} \mathrm{C}\end{array}$ & $\begin{array}{l}\text { Boiling } \\
\text { Point, }{ }^{\circ} \mathrm{C}\end{array}$ & State \\
\hline$n$-propanol & $\mathrm{CH}_{3}\left(\mathrm{CH}_{2}\right)_{2} \mathrm{OH}$ & 60.1 & 0.8 & total & -126.5 & 97.1 & clear, colorless liquid \\
\hline$n$-butanol & $\mathrm{CH}_{3}\left(\mathrm{CH}_{2}\right)_{3} \mathrm{OH}$ & 74.12 & 0.81 & 77 & -89.5 & 117.2 & colorless liquid \\
\hline$n$-pentanol & $\mathrm{CH}_{3}\left(\mathrm{CH}_{2}\right)_{4} \mathrm{OH}$ & 88.15 & 0.8144 & 27 & -77.6 & 138 & colorless liquid \\
\hline$n$-hexanol & $\mathrm{CH}_{3}\left(\mathrm{CH}_{2}\right)_{5} \mathrm{OH}$ & 102.17 & 0.8136 & 5.9 & -46.7 & 158 & colorless liquid \\
\hline$n$-heptanol & $\mathrm{CH}_{3}\left(\mathrm{CH}_{2}\right)_{6} \mathrm{OH}$ & 116.2 & 0.8187 & 1.8 & -34.6 & 175.8 & clear, colorless liquid \\
\hline n-octanol & $\mathrm{CH}_{3}\left(\mathrm{CH}_{2}\right)_{7} \mathrm{OH}$ & 130.23 & 0.824 & $0.3 \mathrm{mg} / 1$ & -16 & 195 & colorless liquid \\
\hline 2-butanol & $\mathrm{CH}_{3} \mathrm{CHOH}\left(\mathrm{CH}_{2}\right) \mathrm{CH}_{3}$ & 74.12 & 0.806 & 125 & -114.7 & 99 & colorless liquid \\
\hline $\begin{array}{l}\text { tert-butanol } \\
(\sim t \text {-butanol) }\end{array}$ & $\mathrm{CH}_{3} \mathrm{C}\left(\mathrm{CH}_{3}\right)_{2} \mathrm{OH}$ & 74.12 & 0.781 & very soluble & 25 & 82 & $\begin{array}{c}\text { colorless liquid or white } \\
\text { solid* }\end{array}$ \\
\hline Isoamyl alcohol & $\left(\mathrm{CH}_{3}\right)_{2} \mathrm{CHCH}_{2} \mathrm{CH}_{2} \mathrm{OH}$ & 88.17 & 0.809 & 25 & -117.2 & 132 & clear, colorless liquid \\
\hline MIBC & $\left(\mathrm{CH}_{3}\right)_{2} \mathrm{CHCH}_{2} \mathrm{CHOHCH}_{3}$ & \multirow{2}{*}{102.17} & \multirow{2}{*}{0.808} & \multirow{2}{*}{17} & \multirow{2}{*}{-90} & \multirow{2}{*}{132} & \multirow{2}{*}{ light brown liquid } \\
\hline ( $\sim$ methyl isobutyl c & jinol) & & & & & & \\
\hline $\begin{array}{l}\text { 4-heptanol } \\
\text { ( 2-ethyl hexanol) }\end{array}$ & $\underset{3}{\mathrm{CH}_{3}\left(\mathrm{CH}_{2}\right)_{2} \mathrm{CH}\left(\mathrm{CH}_{2}\right)_{2} \mathrm{OHCH}}$ & 116.23 & 0.8183 & 4.5 & -41.2 & 161 & liquids \\
\hline Diacetone alcohol & $\mathrm{C}_{6} \mathrm{H}_{12} \mathrm{O}_{2}$ & 116.16 & 0.938 & total & -47 & 166 & clear, colorless liquid \\
\hline TEXANOL & $\mathrm{C}_{12} \mathrm{H}_{24} \mathrm{O}_{3}$ & 216.32 & 0.95 & 20 & -50 & 244 & liquid \\
\hline
\end{tabular}

boiling range $135-140^{\circ} \mathrm{C}$, and flash point of $55^{\circ} \mathrm{C}$. These frothers gave less persistent froth than the other alcohol mixtures.

\section{B) Cyclic Alcohols and Natural Oils}

These frothers are basically mixtures of different cyclic alcohols, ethers, terpineols, and ketones, which can be produced as synthetic mixture or form the pine resins. The basic structures of different components of cyclic alcohol frothers and natural oil members are shown in Fig. (8). The most abundant cyclic alcohols in the frother mixtures are terpineols (i.e. 90 percent) followed by borneol and pinene. The physical and chemical characteristics of cyclic alcohol frothers are shown in Table 4. Terpineol is naturally occurring monoterpene alcohol that has been isolated from a variety of sources such as cajuput oil, pine oil, and petitgrain oil. In addition, terpineols are commonly manufactured from the more readily available $\alpha$-pinene. Borneol can be synthesized by reduction of camphor by the Meerwein-Ponndorf-Verley process [12]. Fenchyl alcohol can be prepared by reduction of fenchone during its purification [20]. Pinene, as the name suggests, both forms are important constituents of pine resin. They are also found in the resins of many other conifers, and more widely in other plants. $\alpha$-Pinene is produced from geranyl pyrophosphate, via cyclisation of linaloyl pyrophosphate followed by loss of a proton from the carbocation equivalent [12].

The cyclic alcohol frothers are less sensitive to the presence of clay minerals than other types of frothers and they are then extensively used in mixtures with aliphatic alcohol frothers for flotation of base metals and copper porphyry ores containing clay minerals. They are also used as additives to tall oil fatty acid in fatty acid flotation to improve froth stability [7].

The major problem in the use of natural oils and cyclic alcohol frothers derived from natural sources is that their composition is not always constant, and consequently frothing properties are variable. In the early days of flotation, eucalyptus oil was a popular frother cum collector. Later, pine oil became the dominant natural oil frother, because of its greater availability in the western world. Essentially all the pine growing countries such as Canada, USA, Finland, China, etc., have supplied different grades of pine oils at one time or another, but from the flotation point of view the problems that mill operators have faced is the difficulty in specifying a particular grade and obtaining the same frother performance from different suppliers. This problem, and the fact that the natural oils all have collector properties, have made them less popular with modern mill operators who now prefer MIBC and synthetic non-collecting soluble frothers. Those using pine oils emphasize on its small-bubble, closely knit, froths that do not allow excessive particle fallout, but break down readily in the launder. The close-knit pine oil froth makes recovery better but lowers the grade of concentrate. Increasing the amount of pine oil fed to the cells tends to flatten the froth, decrease its volume, and cause surface spatter. An emergency supply of pine oil can be very useful at mills with ores which tend to have periods of overfrothing. It can also be used in blends with MIBC to regulate the characteristics of the froth and compensate for changes in ores which may affect selectivity and rougher recovery. Typical specifications for pine oil to be used as a frother are 
<smiles>CC1=CCC(C(C)(C)O)CC1</smiles>

alpha-terpineol<smiles>CC1=CCC2CC1C2(C)C</smiles>

alpha-pinene<smiles>CC12CCC(CC1=O)C2(C)C</smiles>

alpha-camphor<smiles>CC12CCC(CC1)C(C)(C)COC2</smiles>

Eucalyptol

$(1,8$-cineole $)$<smiles>C=C(C)C1CCC(C)(O)CC1</smiles>

beta-terpineol<smiles>CC1(C)C2CCC1(C)C(O)C2</smiles>

Borneol<smiles>CC1=CC(=O)C(C(C)C)CC1</smiles><smiles>CC(C)=C1CCC(C)(O)CC1</smiles>

gama-terpineol<smiles>CC12CCC(C1)C(C)(C)C2O</smiles>

Fenchyl alcohol<smiles>CC12CCCC(CC1)C(C)(C)C2=O</smiles>

Fenchone

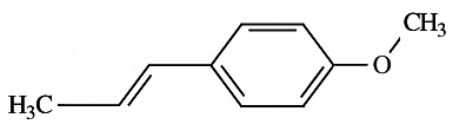

Anethol(e)

Fig. (8). Chemical structures of different components of cyclic alcohols and natural oil $[7,12,14]$.

clear, yellow oil, with a typical smell, that boils between 170 and $228^{\circ} \mathrm{C}$, with density of 0.915 to $0.935 \mathrm{~g} / \mathrm{ml}$. At least 44 percent by weight of the composition should be alcohols (expressed as terpineols). At least 78 percent must distil between 170 and $220^{\circ} \mathrm{C}$. Its average solubility in water should be approximately $2.5 \mathrm{~g} / \mathrm{l}$. For example, a typical assay of commercial pine oil is $\alpha$-terpineol $60-70$ percent, tertiary alcohols 10 percent, borneol and fenchyl alcohol 10-15 percent, and camphor 10-15 percent. Typical properties are a specific gravity of $0.927-0.940$, distillation range $200-235^{\circ} \mathrm{C}$, and flash point of $172^{\circ} \mathrm{C}$. The eucalyptus oils have greater collector action because they are richer in ketones than the pine oils, which contain primarily camphor, while eucalyptus oil ketones are cineoles and piperitones rather than camphor, and borneols and piperoteols, as well as terpenes. Their main odorous component is the ether 1,8-cineole rather than the ketone, camphor. Typical eucalyptus oils available today have a specific gravity of 0.921-0.923, distillation range 174$177^{\circ} \mathrm{C}$, and typical water solubility of $1.4 \mathrm{~g} / 1$ [14].

Table 4 also shows the physical and chemical characteristics of the main components of natural oils. Anethol(e) is commercially prepared from some essential oils, including anise, star anise, and fennel. Eucalyptol or 1,8-cineole comprises up to 90 percent of the essential oil of some species of the generic product eucalyptus oil, hence so name. It is also found in camphor laurel, bay leaves, tea tree, mugwort, 
Table 4. Physical and Chemical Properties of Cyclic Alcohol Frothers and Natural oil Components [7,12,14,21,22]

\begin{tabular}{|c|c|c|c|c|c|c|c|c|}
\hline & Formula & $\begin{array}{l}\text { Polar } \\
\text { Group }\end{array}$ & $\begin{array}{l}\text { Mw, } \\
\text { g/mol }\end{array}$ & $\begin{array}{l}\text { Density, } \\
\text { g/ml }\end{array}$ & $\begin{array}{l}\text { Solubility, } \\
\text { g/l }\end{array}$ & $\begin{array}{l}\text { Freezing } \\
\text { Point, }{ }^{\circ} \mathrm{C}\end{array}$ & $\begin{array}{c}\text { Boiling } \\
\text { Point, }{ }^{\circ} \mathrm{C}\end{array}$ & State \\
\hline \multicolumn{9}{|l|}{ Cyclic alcohols: } \\
\hline$\alpha$-terpineol & $\mathrm{C}_{10} \mathrm{H}_{18} \mathrm{O}$ & $-\mathrm{OH}$ & 154.25 & 0.919 & 2.2 & 33 & 219 & clear liquid \\
\hline$\beta$-terpineol & $\mathrm{C}_{10} \mathrm{H}_{18} \mathrm{O}$ & $-\mathrm{OH}$ & 154.25 & 0.935 & 1.98 & 35 & 220 & clear liquid \\
\hline$\gamma$-terpineol & $\mathrm{C}_{10} \mathrm{H}_{18} \mathrm{O}$ & $-\mathrm{OH}$ & 154.25 & 0.925 & 2.09 & 36 & 222 & clear liquid \\
\hline Borneol & $\mathrm{C}_{10} \mathrm{H}_{18} \mathrm{O}$ & $-\mathrm{OH}$ & 154.25 & 1.011 & 0.64 & 204 & 213 & white solid \\
\hline $\begin{array}{l}\text { Fenchyl alcohol } \\
(\sim \text { fenchol })\end{array}$ & $\mathrm{C}_{10} \mathrm{H}_{18} \mathrm{O}$ & $-\mathrm{OH}$ & 154.25 & 0.992 & insoluble & 37 & 202 & oily liquid or white colorless solid* \\
\hline \multicolumn{9}{|l|}{ Ethers: } \\
\hline Anethol(e) & $\mathrm{C}_{10} \mathrm{H}_{12} \mathrm{O}$ & $\mathrm{O}-\mathrm{C}$ & 148.2 & 0.998 & insoluble & 20 & 234 & clear, colorless liquid \\
\hline $\begin{array}{l}\text { Eucalyptol } \\
(\sim 1,8 \text {-cineole })\end{array}$ & $\mathrm{C}_{10} \mathrm{H}_{18} \mathrm{O}$ & $\mathrm{O}-\mathrm{C}$ & 154.25 & 0.923 & insoluble & 1.5 & $176-177$ & colorless liquid \\
\hline \multicolumn{9}{|l|}{ Terpenes: } \\
\hline$\alpha$-pinene & $\mathrm{C}_{10} \mathrm{H}_{16}$ & - & 136.24 & 0.86 & insoluble & -65 & 155 & liquid \\
\hline \multicolumn{9}{|l|}{ Ketones: } \\
\hline$\alpha$-camphor & $\mathrm{C}_{10} \mathrm{H}_{16} \mathrm{O}$ & $\mathrm{C}=\mathrm{O}$ & 152.23 & 0.99 & 1.2 & 179.75 & 204 & white or colorless solid \\
\hline Piperitone & $\mathrm{C}_{10} \mathrm{H}_{16} \mathrm{O}$ & $\mathrm{C}=\mathrm{O}$ & 152.23 & 0.933 & insoluble & -20.20 & $233-235$ & clear, light yellowish to yellow liquid \\
\hline Fenchone & $\mathrm{C}_{10} \mathrm{H}_{16} \mathrm{O}$ & $\mathrm{C}=\mathrm{O}$ & 152.23 & 0.948 & $\begin{array}{l}\text { slightly } \\
\text { soluble }\end{array}$ & 6.1 & 193.5 & colorless oily liquid \\
\hline
\end{tabular}

${ }^{*}$ depending on the ambient temperature.

sweet basil, wormwood, rosemary, sage and other aromatic plant foliage. Eucalyptol with purity from 99.6 to 99.8 percent can be obtained in large quantities by fractional distillation of eucalyptus oil. Camphor can be produced from $\alpha$ pinene. With acetic acid as the solvent and with catalysis by a strong acid, $\alpha$-pinene readily rearranges into camphene, which in turn undergoes Wagner-Meerwein rearrangement into the isobornyl cation, which is captured by acetate to give isobornyl acetate. Hydrolysis into isoborneol followed by dehydrogenation gives camphor. In biosynthesis camphor is produced from geranyl pyrophosphate, via cyclisation of linaloyl pyrophosphate to bornyl pyrophosphate, followed by hydrolysis to borneol and oxidation to camphor. Piperitone is a natural monoterpene ketone which is a component of some essential oils [12].

Fenchone is a constituent of absinthe and the essential oil of fennel. For its purification, the accompanying substances found in fraction 190 to $195^{\circ} \mathrm{C}$ are removed by oxidation with either concentrated nitric acid or permanganate solution. Fenchone, being very stable toward oxidizing agents, is affected but little. Having thus been purified in a fair measure, it congeals in the cold and can be further purified by crystallization. However, small amounts of camphor, resulting from the oxidation of borneol esters, can not be removed in this manner. Artificially fenchone is obtained by the oxidation of fenchyl alcohol [20].

\section{C) Alkoxy Paraffins}

This group of frothers was developed in 1951 by Dr. Powell of South Africa. In recent years, a number of frothers were produced based on two main structures of TEB $(1,1,3$ triethoxybutane) and Powell accelerator, so named because it has a strong effect on the flotation rate (Fig. 9). The Powell accelerator is a more powerful frother than TEB, but otherwise has similar characteristics, i.e. low water solubility, good stability, and a strong effect on flotation rate. Only limited information is available on the chemistry and properties of these frothers, although they are extensively used for flotation of base metals and oxidic mineral ores. Their frothing properties are much different from those of aliphatic and cyclic alcohols with respect to froth stability and sensitivity to the presence of clay minerals. The froths these reagents produce are similar to those of pine oil, except that overfeeding does not affect the froth character as much. They are selective and in many cases, improve rates of flotation of copper and zinc minerals. These frothers are highly effective during the flotation of oxide copper minerals using the sulfidization method [7,14].

\section{D) Polvglvcol Ethers}

Tveter [23] of Dow Chemicals Company and Booth [24] of American Cyanamid laboratories first developed the polyglycol ether frother series which are completely miscible in water. These frothers are manufactured from synthetic brake fluid and they are methoxy polypropylene glycols or polypropylene glycol methyl ethers. There are several variations of polyglycol ethers produced by different manufacturers, such as Dow Chemical Company under the name Dowfroths (DF\#), by Union Carbide as Ucon frothers, by Cyanamid as Aerofroths (AF\#), ICI as Tecfroths, etc. With MIBC they 
<smiles>CCOC(C)C(OCC)OCC</smiles>

1,1,3-triethoxybutane (TEB)

Fig. (9). Chemical structures of two main alkoxy paraffins [7].

account for nearly 90 percent of all frother use in metallic ore flotation. The three basic structures of these frothers are shown in Fig. (10) [7,14].

(a)

$$
\left.\mathrm{H}-\mathrm{O}-\mathrm{C}_{3} \mathrm{H}_{6}\right]_{n} \mathrm{OH}
$$

$$
\left.\mathrm{CH}_{3}-\mathrm{O}-\mathrm{C}_{3} \mathrm{H}_{6}\right]_{n} \mathrm{OH}
$$

$$
\left.\mathrm{CH}_{3}-\mathrm{O}-\mathrm{C}_{3} \mathrm{H}_{6}\right] \frac{\mathrm{OH}}{n}+\text { adduct }
$$

Fig. (10). Different structures of polyglycol ether frothers [7].

The Dowfroths are usually methoxy polypropylene glycols, with the general structure (a), e.g. DF-200, DF-250 and DF-1012. The Dowfroth 250 is one of the most common used ether frothers, which can be made from the reaction of methanol and propylene oxide. Dowfroth 1400 is a diol of 400 molecular weights, with the structure (b). The American Cyanamid products are condensations of propylene oxide with propylene glycol. Aerofroth 65 (AF-65) is an example of such products, which is prepared by the reaction of propylene oxide with water. Union Carbide supplies similar products based on polypropylene glycols and polyethylene glycols, under the trademarks of PPG and Ucon. Some polyglycol ethers are also produced by condensation with butanol or ethylene oxide (structure (c)) or result as a reaction product of butanol and caustic soda. Dowfroth 1263 is an example of these ethers, which is made by reacting DF-250 with butylenes oxide [7,14,24-29].

The molecular weight and carbon length of polyglycol ether frothers determine their power and performance. A higher molecular weight frother gives more persistent froth and less selective than a lower molecular weight frother. The physical and chemical characteristics of polyglycol ether frothers are shown in Table 5. Unfortunately, the polyglycol ethers from different manufacturers act differently. For example, Hoechst (Germany) polyglycol ether frothers gave more selective froth than those produced by Dow Chemical Company. Fig. (11) shows another example for DF-250 produced by two different American and Canadian manufacturers, in term of surface activity. In experience, polyglycol ethers produced from butanol and ethylene oxide are more selective and have better carrying power than similar frothers produced from butanol and caustic soda $[7,30]$.

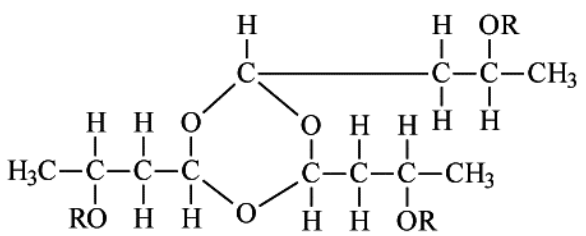

1,3,5-trialkoxypropyl trioxane

(Powell accelerator)

\section{E) Polypropylene Glycol Ethers}

These non-ionic ether frothers are partially soluble in water, and are a mixture of monomethyl ethers of polypropylene glycols, which were first offered by Dow Chemical as DF-4082 and Union Carbide as R17 and R48. These frothers are normally used in base-metal flotation. They produce persistent froth and have relatively high carrying power $[7,14]$. Fig. (12) shows the formula of these frothers.

\section{F) Polyglycol Glycerol Ethers}

Originally, these frothers were developed in the former Soviet Union under the trademark of Frother E1, and in 1985 Dow Chemical, under the trade names XK35004.00L, XK35004.01L and XK35004.02L, produced similar frothers. An example of the second family is the reaction product of glycerol with propylene oxide to a 450 molecular weight $[7,14]$. The general formula of these frothers is shown in Fig. (13).

These frothers produce relatively strong froth with a fine texture. XK35004.01L and XK35004.02L can be blended with other polyglycol ethers to fine tune froth properties. They are stable in the range $\mathrm{pH} 3.5$ to 12.3 , and usually employed in alkaline flotation [14]. The physical and chemical characteristics of polyglycol ether frothers are shown in Table 6.

\subsection{Solubility Based Classification}

Crozier [14] has divided the frothers into slightly soluble in water, and those that are completely miscible. Partially soluble frothers include aliphatic alcohols, natural oils, cresylic acids, alkoxy paraffins and non-ionic polypropylene glycol ethers. The solubility data of these frothers is listed in Tables 2 to 4 . In the case of aliphatic alcohols, the alcohols with lower solubility are more effective than those with higher solubility. Completely water miscible frothers are polyglycol and polyglycol glycerol ethers. These frothers produce compact, lasting froth structures that break down readily in the launders. Unlike the froths from slightly soluble frothers, these frothers produce more tightly knit, more selective froths, that do not spatters on over-feeding the reagent.

\subsection{Frothing/Collecting Ability Based Classification}

The ability of compound to demonstrate frothing properties has been associated with chemical groups such as hydroxyl $(-\mathrm{OH})$, carboxyl $(-\mathrm{COOH})$, ester (-COOR), carbonyl $(-\mathrm{CO})$, nitrogen-containing $\left(\mathrm{NH}_{2}\right.$ and $\left.\mathrm{N}\right)$, and sulfurcontaining $\left(-\mathrm{SO}_{3}-\right)$ groups. Considering such a behavior, the 
Table 5. Physical and Chemical Properties of Polyglycol Ether Frothers ${ }^{*}[7,14,27,29,31,32]$

\begin{tabular}{|c|c|c|c|c|c|c|c|}
\hline & Formula & Mw, g/mol & $\begin{array}{l}\text { Viscosity at } \\
25^{\circ} \mathrm{C}, \text { cps }\end{array}$ & $\begin{array}{c}\text { Density, } \\
\text { g/ml }\end{array}$ & $\begin{array}{c}\text { Solubility, } \\
\text { g/l }\end{array}$ & $\begin{array}{l}\text { Freezing } \\
\text { Point, }{ }^{\circ} \mathrm{C}\end{array}$ & $\begin{array}{c}\text { Boiling } \\
\text { Point, }{ }^{\circ} \mathrm{C}\end{array}$ \\
\hline \multicolumn{8}{|l|}{ Dow Chemical: } \\
\hline DF-200 & $\mathrm{CH}_{3}\left(\mathrm{C}_{3} \mathrm{H}_{6} \mathrm{O}\right)_{3} \mathrm{OH}$ & 206.29 & 7 & 0.97 & total & -50 & 243 \\
\hline DF-250 & $\mathrm{CH}_{3}\left(\mathrm{C}_{3} \mathrm{H}_{6} \mathrm{O}\right)_{4} \mathrm{OH}$ & 264.37 & 12 & 0.98 & Total & -50 & 252 \\
\hline DF-1012 & $\mathrm{CH}_{3}\left(\mathrm{C}_{3} \mathrm{H}_{6} \mathrm{O}\right)_{6.3} \mathrm{OH}$ & 397.95 & 27 & 0.988 & $32 \%$ & -50 & 293 \\
\hline DF-400 & $\mathrm{H}\left(\mathrm{C}_{3} \mathrm{H}_{6} \mathrm{O}\right)_{6.5} \mathrm{OH}$ & 395.61 & 71 & 1.007 & total & -50 & 180 \\
\hline DF-1400 & $\mathrm{H}\left(\mathrm{C}_{3} \mathrm{H}_{6} \mathrm{O}\right)_{6} \mathrm{OH}$ & 366.56 & 75 & 1.007 & total & -45 & \\
\hline DF-1263 & $\mathrm{CH}_{3}\left(\mathrm{C}_{3} \mathrm{H}_{6} \mathrm{O}\right)_{4} \mathrm{OH}\left(\mathrm{C}_{4} \mathrm{H}_{8} \mathrm{O}\right)$ & 336.53 & 19 & 0.978 & very good & -41 & $>250$ \\
\hline \multicolumn{8}{|l|}{ Union Carbide: } \\
\hline Ucon 200 & & 400 & 75 & 1.009 & total & -45 & \\
\hline Ucon R55 & & & & 0.9735 & total & -50 & \\
\hline PPG-192 & $\mathrm{H}\left(\mathrm{C}_{3} \mathrm{H}_{6} \mathrm{O}\right)_{3} \mathrm{OH}$ & $192^{\mathrm{a}}$ & & & & & \\
\hline PPG-400 & $\mathrm{H}\left(\mathrm{C}_{3} \mathrm{H}_{6} \mathrm{O}\right)_{6.5} \mathrm{OH}$ & $420^{\mathrm{a}}$ & & & & & \\
\hline PPG-725 & $\mathrm{H}\left(\mathrm{C}_{3} \mathrm{H}_{6} \mathrm{O}\right)_{12.8} \mathrm{OH}$ & $762^{\mathrm{a}}$ & & & & & \\
\hline PPG-1000 & $\mathrm{H}\left(\mathrm{C}_{3} \mathrm{H}_{6} \mathrm{O}\right)_{16.5} \mathrm{OH}$ & $950^{\mathrm{a}}$ & & & & & \\
\hline PPG-2000 & $\mathrm{H}\left(\mathrm{C}_{3} \mathrm{H}_{6} \mathrm{O}\right)_{34} \mathrm{OH}$ & $1940^{\mathrm{a}}$ & & & & & \\
\hline \multicolumn{8}{|l|}{ Cyanamid: } \\
\hline AF-65 & similar to DF-400 & & & & & & \\
\hline AF-67 & similar to DF-250 & & & & & & \\
\hline AF-68 & similar to DF-1012 & & & & & & \\
\hline
\end{tabular}

${ }^{*}$ These frothers all are in liquid state.

a These data are characterized by reversed-phase high performance liquid chromatography (HPLC) as reported by Tan et al. [31].

compounds commercially used as frothers in mineral/coal froth flotation today can be classified into two general categories. The first category is the group that acts in a flotation system as both collector and frother and is normally associated with non-sulfide mineral flotation. The compounds be-

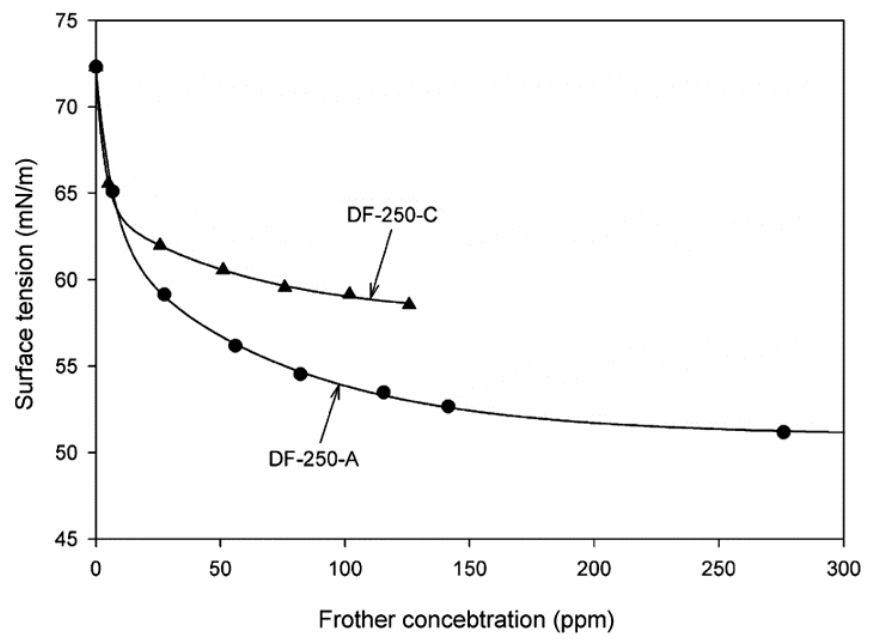

Fig. (11). Variation of surface tension with concentration of American (A) and Canadian (C) DF-250 [30]. longed to this category consist of carboxylic, nitrogen- and sulfur-containing groups. Typical members are long-chain amines and amine salts which have chain lengths up to $\mathrm{C}_{18}$ (used, for example, as cationic collectors in the flotation of silica), the long-chain sulfates (e.g., petroleum sulfonates), and long-chain fatty acids (which generally include, in varying ratios, $\mathrm{C}_{18}$ fatty acids, oleic, linoleic, and linolenic acids). The above materials are ionic and highly surface-active and can result in the formation of stable and persistent froths if overdosed. Because of the soluble metal ion sequestration and the adsorption of most of these dual collector/frother compounds on the substrate to be recovered, the actual chemical equilibrium concentration in the system is relatively low. Thus, reasonable froth action is exhibited in most practical systems by dual functions compounds. However, because of the high surface activity related to the ionic character of these dual function compounds, if the concentration available for frother action becomes too high, very stable and difficult to handle froths will result $[33,34]$.<smiles>CCOCCOC(C)(C)C</smiles>

Fig. (12). Chemical structure of polypropylene glycol ethers [7]. 
<smiles>[R]OC(C)CO</smiles>

$R=4$ to 6 carbon atoms

Fig. (13). Chemical structure of polyglycol glycerol ethers [7].

The second category is frothers containing the hydrophilic group $\mathrm{OH}$. The $\mathrm{OH}$ group has strong hydrophilic properties and is very weakly-adsorbed on minerals (while the exception of coal and probably other naturally hydrophobic minerals). Therefore, frothers containing this group possess comparatively weak collecting action. The properties of different frothers containing $\mathrm{OH}$ group depend on the structure of the hydrophobic group, the number of $\mathrm{OH}$ groups in the molecule of frother and their disposition in relation to the hydrophilic portion. Phenols, terpineols, alcohols, alkoxytype materials, and polypropylene glycol ethers are the main members of this category [33].

\subsection{Selectivity/Frothing-Power Based Classification}

Based on direct experimental observations in both batch laboratory and continuous large scale flotation cells, the use of a frother significantly increases first, the possibility of a particle-bubble contact, and second, the efficiency of sticking after such a contact. Thus, a major role of a frother is to significantly increase the rate of flotation [34]. With respect to this role, two terms of "selective" and "powerful" are used to characterize frothers. The former refers to the attachment of a hydrophobic particle to an air bubble, which can be used in flotation of very fine particles, whereas the latter which indicates the frothing capacity of the frother, will provide higher recoveries and better performance in floating of coarser particles [2,14,32].

There are two diagrams to characterize the selectivity and power of a frother. The first is the HLB-Molecular weight diagram (HLB stands for hydrophile-lipophile balance) shown in Fig. (14). As seen, the frothers which fall on the left side of this diagram are known to be selective in flotation, while the ones which are situated far to the right from this line are known to exhibit properties of strong flotation frothers [32].

Based on the laboratory experiences and literature findings broadly emerge that frothers belonging to alcohol and ketone family are selective for ultrafine particle size fraction and polyglycol frother and aldehyde are effective to float coarse fraction. Branched and water soluble alcohol and ketone molecules produce mono and finer bubble size which enhance the separation efficiency of finer particle size fraction. Polyglycol ether and aldehyde molecules are more sur- face active and produce more stable and viscous froth compared to alcohol frothers, which leads the recovery of coarse particle size fraction of flotation feed. Therefore, it is difficult to use a single frother that will effectively give good overall flotation performance for wide particle size distributed flotation feed [35-37]. This suggests potential benefits of blending frothers for improved overall valuable recovery. For example, Laskowski et al. [38] tested a series of frother blends prepared by mixing MIBC with different polyoxypropylene alkyl ethers, including DF-200, DF-250 and DF-1012, through the determination of dynamic frothability index (DFI) and critical coalescence concentration (CCC), as will be discussed later. Table 7 shows CCC and DFI values for individual frothers and their blends. As seen, the blends shows better frothing behavior compared to MIBC but less effective than Dowfroth frothers.

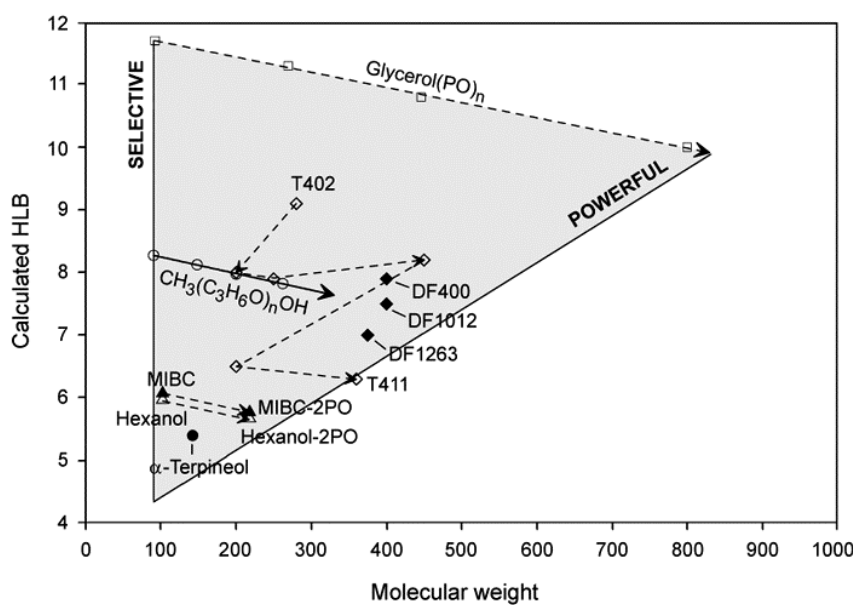

Fig. (14). The HLB-Molecular weight diagram for flotation frothers [32].

Gupta et al. [37] conducted a research program to determine the effects of the frother mixture on the froth flotation performance for a wide size distributed coal flotation feed. In this regard, three mixed frother systems were prepared as frother " $x$ " composed of alcohol and ketone, frother " $y$ " consisted of alcohol and aldehyde group chemicals, and frother " $z$ " a blended product of alcohol and polyglycol ether. The following conclusions were drawn from their work:

- Alcohol and polyglycol ether mixed frother " $z$ " was clearly superior compared to mixed frother " $x$ " of alcohol and ketone and mixed frother "y" of alcohol and aldehyde in terms of selectivity and kinetics.

- In terms of ash reduction and recovery, frother " $z$ " was efficient for coarse and ultrafine particle size fractions. It could be described by the presence of short chain alcohol

Table 6. Physical and Chemical Properties of Polyglycol Glycerol Ether Frothers [14]

\begin{tabular}{|l|c|c|c|c|}
\hline & Ave. Mw, g/mol & Specific Gravity & Viscosity at 25 ${ }^{\mathbf{0}}, \mathbf{c p s}$ & Solubility, $\mathbf{g} / \mathbf{l}$ \\
\hline \hline XK35004.00L & 450 & 1.05 & 510 & tash Point, ${ }^{\mathbf{0}} \mathbf{C}$ \\
\hline XK35004.01L & 250 & 1.09 & 600 & total \\
\hline XK35004.02L & 700 & 1.03 & 205 & total \\
\hline
\end{tabular}


Table 7. DFI and CCC Values for Individual Frothers and Their Blends Investigated by Laskowski et al. [38]

\begin{tabular}{|l|c|c|c|c|}
\hline \multirow{2}{*}{} & \multicolumn{2}{|c|}{ Mole Fraction } & \multirow{2}{*}{ CCC, mmol/dm ${ }^{3}$} & DFI, s.dm $\mathbf{m}^{\mathbf{3}} \mathbf{m o l}$ \\
\cline { 2 - 5 } & MIBC & Dowfroth & 0.11 & 34,000 \\
\hline \hline MIBC & 1 & - & 0.094 & 106,000 \\
\hline MIBC/DF-200 & 0.56 & 0.44 & 0.067 & 108,000 \\
\hline MIBC/DF-250 & 0.78 & 0.22 & 0.049 & 94,000 \\
\hline MIBC/DF-1024 & 0.89 & 0.11 & 0.089 & 196,000 \\
\hline DF-200 & - & 1 & 0.033 & 208,000 \\
\hline DF-250 & - & 1 & 0.015 & 267,000 \\
\hline DF-1024 & - & 1 & \\
\hline
\end{tabular}

molecules (which is selective for ultrafine fraction; see Fig. (14)) and polyglycol ether molecules (which is stronger frother for coarse size fraction) in frother " $z$ ".

- Frother "z", which contains polyglycol ether and alcohol molecule, was more surface active in reducing the surface tension compared to other two frothers.

- Frother " $z$ " was a more surface active and selective frothing chemical. Synergistic effects in flotation performance occurred with polyglycol ether and short chain alcohol mixed chemical system.

In the second diagram, dynamic frothability index (DFI) values are plotted versus critical coalescence concentration (CCC) values as shown in Fig. (15). Laskowski [32, 35] compared the DFI-CCC and HLB-Molecular weight diagrams and showed that the DFI-CCC diagram can be used to classify frothers. The frothers which are situated in the upper-left corner of the diagram are very powerful, while those situated in the bottom-right corner are selective. Table 8 shows the HLB, molecular weight, DFI, and CCC values of flotation frothers.

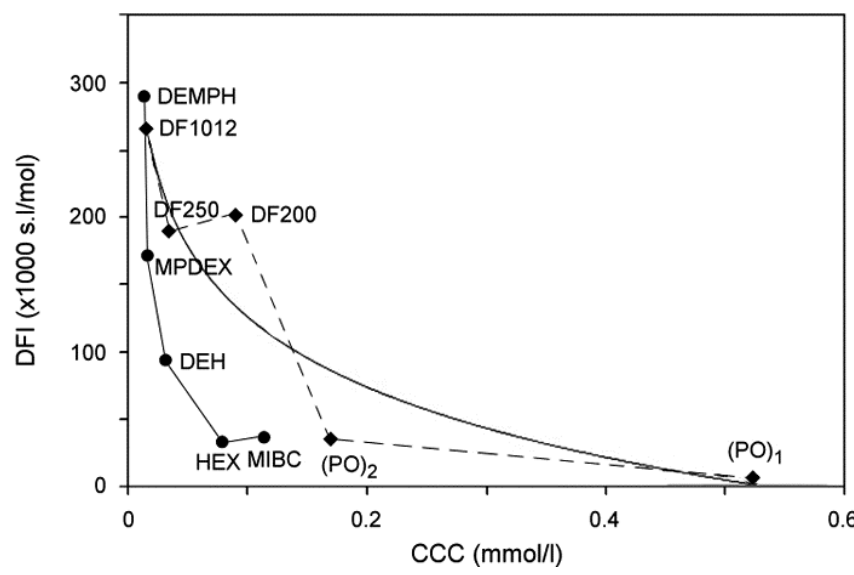

Fig. (15). Relationship between DFI and CCC values for flotation frothers [32].

\section{NEW CLASSES OF FROTHERS}

Although a new reagent might result in an increase mineral recovery of only about 1 percent over traditional rea- gents, this small improvement is of great economic importance for industrial operations that process thousands tones of ore daily. At such high throughput rates, relatively small improvements in mineral recovery can result in the production of significant additional tones of minerals daily. As is well known, the surface activity of any surfactant is determined by its chemical structure, and incorporating certain functional "group" or "atoms" into the molecular structure of the surfactant will strongly influence its properties [27]. In this regard, several investigators have tried to improve commercially used frothers, in both terms of selectivity and frothing-power.

Keys [43] introduced a new class of frothers which were actually a series of modified alcohol frothing agents, comprising at least one hydroxyl group. These modified frothers were selected from the groups consisting of:

- the reaction product of a $\mathrm{C}_{5}-\mathrm{C}_{10}$ diol and a $\mathrm{C}_{1}-\mathrm{C}_{7}$ carboxylic acid in a ratio of one mole of carboxylic acid per mole of diol and having the predominant structure (a) in Fig. (16), in which $n$ is $5-10$ and $x$ is $0-6$;

- the reaction product of a $\mathrm{C}_{5}-\mathrm{C}_{10}$ diol and acrylonitrile in a one to one mole ratio of acrylonitrile to diol such that the reaction product retains at least one hydroxyl group and having the predominant structure (b) in Fig. (16), in which $n$ is $5-10$ and $m$ is $0-3$;

- the reaction product of between about 1 and 10 moles of a $\mathrm{C}_{2}-\mathrm{C}_{3}$ alkylene oxide per mole of a $\mathrm{C}_{1}-\mathrm{C}_{7}$ carboxylic acid and having the predominant structure (c) in Fig. (16), in which $x$ is $0-6, y$ is $2-3$, and $z$ is $1-10$;

- the reaction product of a $\mathrm{C}_{2}-\mathrm{C}_{4}$ alkylene oxide and one mole of $\mathrm{C}_{5}-\mathrm{C}_{10}$ diol having the predominant structure (d) in Fig. (16), in which $n$ is $5-10, y$ is $2-3$, and $z$ is $1-10$;

- the reaction product of a $\mathrm{C}_{2}-\mathrm{C}_{4}$ alkylene oxide and an acrylonitrile; and

- mixtures thereof.

Advantages of these modified alcohol frothers include excellent recovery yields of sulfide particles in the froth flotation and improved flotation kinetics of the particles for increased throughput of ore subjected to the process. Other advantages are the ability of these frothers to operate in harmony with sulfide collectors, and the ability to utilize lower 
Table 8. HLB, Molecular Weight, DFI, and CCC Values for Flotation Frothers

\begin{tabular}{|c|c|c|c|c|c|}
\hline & \multirow{2}{*}{ Mw, g/mol } & \multirow{2}{*}{ HLB } & \multirow{2}{*}{ DFI, s.dm $\mathbf{d m}^{3} / \mathrm{mol}$} & \multicolumn{2}{|c|}{$\mathrm{CCC}$} \\
\hline & & & & mmol/l & ppm \\
\hline \multicolumn{6}{|l|}{ Aliphatic alcohols: } \\
\hline$n$-propanol & 60.1 & $7.5^{\mathrm{a}}$ & & & \\
\hline$n$-butanol & 74.12 & $7^{\mathrm{a}}$ & $1,339^{\mathrm{b}}$ & & \\
\hline$n$-butanol ${ }^{*}$ & 74.12 & $7^{\mathrm{a}}$ & $1,271^{\mathrm{b}}$ & & \\
\hline 2-butanol & 74.12 & $7^{\mathrm{a}}$ & $826^{\mathrm{b}}$ & & \\
\hline$t$-butanol & 74.12 & $7^{\mathrm{a}}$ & $1,588^{b}$ & & \\
\hline$n$-pentanol & 88.15 & $6.5^{\mathrm{c}}$ & $5,517^{\mathrm{b}}$ & & \\
\hline n-hexanol & 102.17 & $6^{\mathrm{d}}$ & $33,779^{\mathrm{b}}$ & & \\
\hline n-heptanol & 116.2 & $5.6^{\mathrm{a}}$ & $40,867^{\mathrm{b}}$ & & \\
\hline$n$-octanol & 130.23 & $5.1^{\mathrm{c}}$ & $79,338^{\mathrm{b}}$ & & \\
\hline Isoamyl alcohol & 88.17 & $6.5^{\mathrm{a}}$ & & & \\
\hline MIBC & 102.17 & $6^{\mathrm{d}}$ & $34,000^{\mathrm{f}} ; 35,020^{\mathrm{g}} ; 36,991^{\mathrm{b}} ; 37,000^{\mathrm{h}}$ & $0.11^{\mathrm{d}}$ & $11.2^{\mathrm{f}, \mathrm{h}} ; 11.5^{\mathrm{e}}$ \\
\hline 2-ethyl hexanol & 116.23 & $5.6^{\mathrm{a}}$ & $141,147^{b}$ & & \\
\hline Diacetone alcohol & 116.16 & $6.4^{\mathrm{e}}$ & $12,000^{\mathrm{b}}$ & & \\
\hline TEXANOL & 216.32 & & & & \\
\hline \multicolumn{6}{|l|}{ Cyclic alcohols: } \\
\hline$\alpha$-terpineol & 154.25 & $5.4^{\mathrm{e}}$ & $137,988^{\mathrm{g}} ; 138,000^{\mathrm{h}} ; 138,901^{\mathrm{b}}$ & & $8^{g}$ \\
\hline \multicolumn{6}{|l|}{ Alkoxy paraffins: } \\
\hline TEB & 176.29 & $6.6^{\mathrm{a}}$ & $252,589^{b}$ & & \\
\hline \multicolumn{6}{|l|}{ Polyglycol ether: } \\
\hline $\mathrm{CH}_{3}\left(\mathrm{C}_{3} \mathrm{H}_{6} \mathrm{O}\right) \mathrm{OH}$ & 90.12 & $8.3^{\mathrm{f}}$ & $5,700^{\mathrm{f}}$ & $0.52^{\mathrm{f}}$ & $46.8^{\mathrm{f}}$ \\
\hline $\mathrm{CH}_{3}\left(\mathrm{C}_{3} \mathrm{H}_{6} \mathrm{O}\right)_{2} \mathrm{OH}$ & 148.12 & $8.15^{\mathrm{f}}$ & $35,000^{\mathrm{f}}$ & $0.17^{\mathrm{f}}$ & $25.1^{\mathrm{f}}$ \\
\hline DF-200 & 206.29 & $8^{f}$ & $196,000^{f}$ & $0.089^{\mathrm{f}}$ & \\
\hline $\mathrm{DF}-250$ & 264.37 & $7.8^{\mathrm{f}}$ & $208,000^{f}$ & $0.033^{\mathrm{f}}$ & \\
\hline DF-1012 & 397.95 & $7.5^{\mathrm{f}}$ & $267,000^{\mathrm{f}}$ & $0.015^{\mathrm{f}}$ & \\
\hline DF-400 & 395.61 & $9.9^{\mathrm{i}}$ & & & \\
\hline DF-1400 & 366.56 & $10^{\mathrm{a}}$ & & & \\
\hline DF-1263 & 336.53 & $7^{\mathrm{e}}$ & & & \\
\hline PPG-192 & $192^{\mathrm{j}}$ & $10.4^{\mathrm{j}}$ & & & \\
\hline PPG-400 & $420^{\mathrm{j}}$ & $9.8^{\mathrm{j}}$ & & & \\
\hline PPG-725 & $762^{\mathrm{j}}$ & $9.2^{\mathrm{j}}$ & & & \\
\hline PPG-1000 & $950^{\mathrm{j}}$ & $8.4^{\mathrm{j}}$ & & & \\
\hline PPG-2000 & $1940^{\mathrm{j}}$ & $5.6^{\mathrm{j}}$ & & & \\
\hline
\end{tabular}

${ }^{*}$ Test conducted in distilled water.

${ }^{\text {a }}$ Calculated by Davies equation

${ }^{\mathrm{b}}$ Cho and Laskowski [39]

${ }^{\mathrm{c}}$ Wang and Yoon [40]

${ }^{\mathrm{d}}$ Laskowski [32]

${ }^{e}$ Rao [5]

${ }^{\mathrm{f}}$ Laskowski [35]

${ }^{g}$ Gupta et al. [41]

${ }^{\mathrm{h}}$ Melo and Laskowski [36]

${ }^{\mathrm{i}}$ Pugh [42]

${ }^{\mathrm{j}}$ Tan et al. [29] 


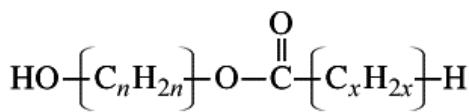

(a)

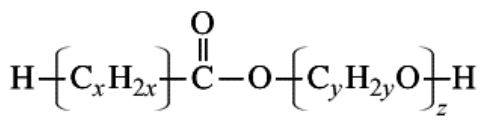

(c)

Fig. (16). Chemical structures of modified alcohol frothers [43].

dosages of them compared to conventional frothers while improving selectivity and kinetics in the flotation.

Biermann et al. [44] used derivatives of tricyclo$\left(5.2 .1 .0^{2,6}\right)$-dec-3-ene as frothers in the flotation of coal, cassiterite, and sulfide ores (Fig. 17). These products were surprisingly found to have excellent properties as flotation frothers which make them at least equivalent and even superior to hitherto known flotation frothers. In addition, it has been found that not only are these derivatives compatible with the other constituents of the flotation pulps, a requirement which conventional frothers have to satisfy, they also have a positive effect on the influence of the collector in the flotation pulp, i.e. they enhance or boost the collector effect, and are thus able to contribute toward reducing the quantity in which the compounds added as collectors are used.

Derivatives of tricyclo- $\left(5 \cdot 2 \cdot 1 \cdot 0^{2,6}\right)$-dec-3-ene have general structure (a) shown in Fig. (17). In this structure $\mathrm{R}^{1}$ is hydrogen or a linear or branched $\mathrm{C}_{1}-\mathrm{C}_{8}$ alkyl radical, such as methyl, ethyl, $n$-propyl, $i$-propyl, $n$-butyl, 2-butyl, $t$-butyl, $n$ pentyl, $n$-hexyl, $n$-heptyl, or $n$-octyl, and isomers thereof. Preferred alkyl radicals are $\mathrm{C}_{1}-\mathrm{C}_{4}$ alkyl radical. Particularly good frother results are obtained where $\mathrm{R}^{1}$ is an ethyl radical. $\mathrm{R}^{1}$ can be an acyl radical of the formula $\mathrm{R}^{2}-\mathrm{CO}-$ where $\mathrm{R}^{2}$ is hydrogen or a linear or branched $\mathrm{C}_{1}-\mathrm{C}_{18}$ alkyl or alkenyl radical, such as ethyl, propyl, butyl, pentyl, hexyl, heptyl, octyl, nonyl, decyl, undecyl, dodecyl, tridecyl, tetradecyl, pentadecyl, hexadecyl, heptadecyl, or octadecyl. $\mathrm{R}^{1}$ can even be a hydroxyalkyl radical of the general structure (b) (Fig. 17), in which $\mathrm{R}^{3}$ and $\mathrm{R}^{4}$ independently of one another are hydrogen or hydroxyl group, and $m$ and $n$ are integers of 0 to 5 and the sum $(m+n)$ is an integer of 1 to 5 , with the proviso that at least one of the substituents $\mathrm{R}^{3}$ and $\mathrm{R}^{4}$ is a hydroxyl group, and/or of mixtures of several isomeric derivatives (structure (a)) as frothers in the flotation processes.

Esters of general structure (a), in which $\mathrm{R}^{1}$ has the meaning $\mathrm{R}^{2}-\mathrm{CO}-$, are prepared by reaction of dicyclopentadiene (or tricyclo-(5.2.1.0 $\left.0^{2,6}\right)$-dec-3,8-diene) corresponding to the structure (c) in Fig. (17), with carboxylic acids corresponding to the general formula $\mathrm{R}^{2} \mathrm{COOH}$, in which $\mathrm{R}^{2}$ is as defined above, in the presence of catalytic quantities of mineral acids. Reactants for the dicyclopentadiene are preferably $\mathrm{C}_{1}$ $\mathrm{C}_{6}$ carboxylic acids, such as acetic acid, propionic acid or caproic acid, or fatty acids obtainable from natural fats and oils by ester cleavage, preferably lauric acid or oleic acid. Ethers corresponding to structure (a), in which $\mathrm{R}^{1}$ is an alkyl or hydroxyalkyl radical are synthesized by reaction of dicyclopentadiene with monohydric or polyhydric alcohols corresponding to the formula $\mathrm{R}^{1} \mathrm{OH}$ or structure (d) (Fig. 17), in which $\mathrm{R}^{1}, \mathrm{R}^{3}, \mathrm{R}^{4}, m$ and $n$ are as defined above. The monohydric alcohols preferably used contain a $\mathrm{C}_{1}-\mathrm{C}_{4}$ alkyl radical as the radical $\mathrm{R}^{1}$. Although it is of particular advantage to use ethanol, polyhydric alcohols may also used for the reaction with dicyclopentadiene. Ethanediol and glycerol are representatives of the polyhydric alcohols particularly suit- (a)
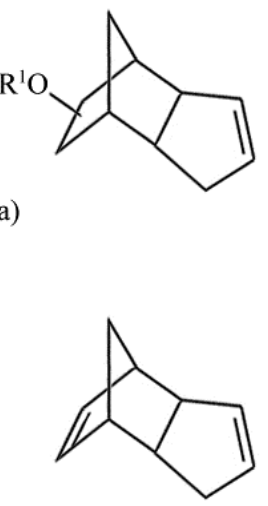

(c)

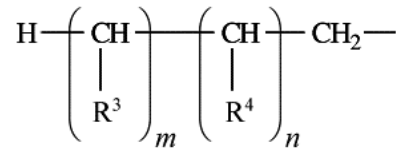

(b)

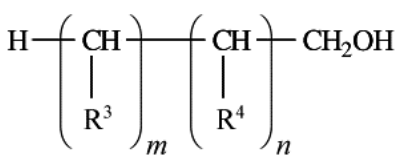

(d)

Fig. (17). General structures of derivatives of tricyclo- $\left(5 \cdot 2 \cdot 1 \cdot 0^{2,6}\right)$-dec-3-ene $(\mathbf{a}, \mathbf{b})$ and their source chemicals (c,d) [44]. 
able for this purpose. The reaction of dicyclopentadiene with mineral acids alone, such as $\mathrm{HCl}$ and $\mathrm{H}_{2} \mathrm{SO}_{4}$, gives $8(9)$ hydroxytricyclo- $\left(5 \cdot 2 \cdot 1.0^{2,6}\right)$-dec-3-ene, i.e. the compound of general structure (a) in which $\mathrm{R}^{1}$ is hydrogen. This reaction is normally carried out at temperatures in the range of from $20^{\circ} \mathrm{C}$ to $150^{\circ} \mathrm{C}$, preferably $40-60^{\circ} \mathrm{C}$, optionally in an organic solvent, such as aliphatic or aromatic hydrocarbons, more especially toluene or xylene or mixtures thereof.

Flotation tests of coal and ores showed that the esters, i.e. compounds in which $\mathrm{R}^{1}$ is $\mathrm{R}^{2}-\mathrm{CO}-$, show slightly better frother properties than the corresponding ethers, i.e. compounds in which $\mathrm{R}^{1}$ is alkyl or hydroxyalkyl. Compared with standard flotation frothers, for example 2-ethyl hexanol, a much higher recovery of coal or ores was achieved. In the flotation of coal, there was considerably less residual ash in the concentrate. Accordingly, the selectivity of these derivatives was very good and had a boosting effect on a number of collectors of the type normally used in flotation processes. The result of this booster effect was that the quantities in which the compounds added as collectors were used might be distinctly reduced.

Klimpel and Isherwood [45] have been studied a new class of frothers of general chemical formula, ROH.n alkylene oxide units with $\mathrm{R}$ in the range 4-6. These frothers are adducts of propylene oxide or butylene oxide, and aliphatic alcohols, such as hexanol• $\left(\mathrm{C}_{3} \mathrm{H}_{6} \mathrm{O}\right)_{2}$, methyl pentanol $\cdot\left(\mathrm{C}_{3} \mathrm{H}_{6} \mathrm{O}\right)_{2}$, and MIBC $\cdot\left(\mathrm{C}_{3} \mathrm{H}_{6} \mathrm{O}\right)_{2}$. The frothers of this family extend the coarse particle range from 20 to $200 \mu \mathrm{m}$, but at the expense of recovering fine particles. This makes it desirable to use appropriate blend of frothers of specific chemical structures to give the broadest particle size range recovery. In addition to the increase in coarse particle recovery demonstrated by the alcohol-propylene oxide combination over the same alcohol alone, increasing the branching of the alcohol backbone gradually decreases the effective particle size range floated by the frother-collector combination. A highly branched trihydric alcohol, glycerol, reacted with propylene oxide is a more effective fine particle frother than any of the alcohols alone [5].

Rasheed [46] introduced a series of sulfonates modified by adding an $n$-ethylene oxide chain to the aromatic base, as shown in Fig. (18) (b,c). The reaction of an ethoxylated alkyl phenol of the formula $\mathrm{R}-\mathrm{Ph}-\mathrm{O}\left(\mathrm{CH}_{2} \mathrm{CH}_{2} \mathrm{O}\right)_{\mathrm{n}} \mathrm{H}$ wherein $\mathrm{R}$ is a straight or branched alkyl group containing 8-12 carbon atoms, $\mathrm{n}$ is $6-10, \mathrm{Ph}$ denotes a phenyl ring and the substituents thereon are in the para-position, with sulfur trioxide forms an intermediate of structure (a). By the reaction of this intermediate product with a hydroxide of the formula $\mathrm{M}-\mathrm{OH}$ wherein $\mathrm{M}$ is lithium, sodium, potassium or ammonium, products of structure (b) is formed. Structure (c) is obtained by desulfurization of the intermediate (structure (a)) through heating the reaction of the intermediate with hydroxide to about $20^{\circ} \mathrm{C}$ to $150^{\circ} \mathrm{C}$, preferably about $60^{\circ} \mathrm{C}$. In the presence of tall oil fatty acids as collectors, these frothers gave desirable results in phosphate flotation.

Harris and Jia [27] introduced a new class of frothers by adding a sulfur atom to polyalkoxylated molecule of various configurations. They showed that these frothers increased metal recovery, both copper and molybdenum, in the flotation of porphyry ores. Table 9 shows the chemical structure and flotation results of these frothers, and MIBC and oxygen-bearing polypropylene for comparison purposes.

Recently, Cappuccitti and Finch [47] developed a new class of frothers resulting from the reaction of aliphatic alcohol $\mathrm{C}_{1}$ (methanol) to $\mathrm{C}_{4}$ (butanol) and mixtures thereof with between 0.2 moles and 5 moles of ethylene oxide. These ethoxylated alcohols correspond generally to the formula $\mathrm{R}_{1}-$ $\mathrm{O}-\left(\mathrm{CH}_{2} \mathrm{CH}_{2} \mathrm{O}\right)_{n} \mathrm{H}$, where, $\mathrm{R}_{1}$ is a straight or branched chain, $\mathrm{C}_{1}$ to $\mathrm{C}_{4}$ alkyl radical and $\mathrm{n}$ is between 0.2 to 5 . These frothers have their own set of hydrodynamic and froth properties that depend on the amount of ethylene oxide reacted with the alcohol. The testing of the new frother chemistries led to identifying ethoxylated butanols (ButOH-nEO, $\mathrm{n}=1.5,2,3$ ) as potential equivalents to MIBC. Ethoxylated butanols offered a range of properties; by changing the number of ethoxy groups products could be made slightly weaker (for $\mathrm{n}=1.5$ ) or stronger (for $\mathrm{n}=2$ and 3 ) than MIBC but the chemistry could not provide hydrodynamic/froth characteristics similar to frothers like glycols and glycol ethers.

\section{BIOFROTHERS}

There are two uses of microorganisms in mineral processing: (1) bioleaching, a long-established technique, in which microorganisms assist in the dissolution of metallic ions for metal recovery from ores; and (2) biobeneficiation, in which microorganisms act as surface modifiers, depressants, collectors or dispersing agents to enhance the separation of minerals by either flotation or flocculation [48].

The use of microorganisms in bioflotation processes was first studied by Solojenleen (1976) who announced the possibility of flotation of ores in the presence of sulphate reducing bacteria (SRB) [49]. Solozhenkin and Lyubavina [50] showed that flotation of cerussite was improved by $20-25$ percent after pretreatment with SRB. Zajic and Kosaric [51] used a mixture of Pseudomonas and Alcaligenes as collectors for flotation of scheelite from calcite. Mycobacterium

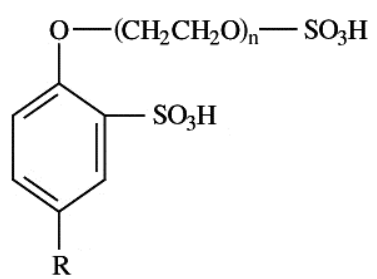

(a)

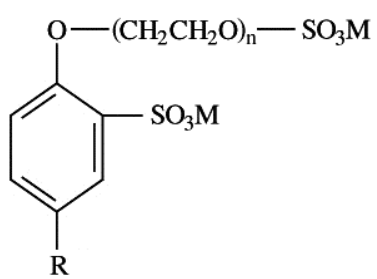

(b)

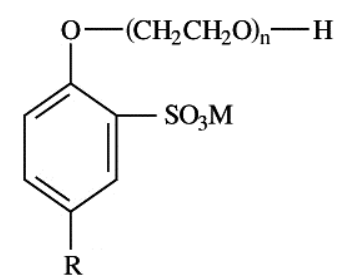

(c)

Fig. (18). Chemical structures of modified sulfonates [46]. 
Table 9. Formula and Flotation Results of Modified Sulfur-Bearing Frothers [27]

\begin{tabular}{|c|c|c|c|c|}
\hline & HLB & Frother Dosage, Kg/Tone & $\begin{array}{c}\% \mathrm{Cu} \\
\text { Recovery }\end{array}$ & $\begin{array}{c}\text { \% Mo } \\
\text { Recovery }\end{array}$ \\
\hline MIBC & 6.1 & 0.105 & 75.28 & 72.66 \\
\hline $\mathrm{CH}_{3} \mathrm{~S}(\mathrm{PO})_{5} \mathrm{H}$ & 4.4 & 0.074 & 76.42 & 73.58 \\
\hline $\mathrm{CH}_{2} \mathrm{~S}(\mathrm{PO})_{2.7} \mathrm{H}$ & 1.9 & 0.110 & 76.45 & 74.51 \\
\hline $\mathrm{H}(\mathrm{PO})_{\mathrm{X}} \mathrm{Sc}_{2} \mathrm{~h}_{4} \mathrm{~s}(\mathrm{PO})_{\mathrm{Y}} \mathrm{h}, \mathrm{X}+\mathrm{Y} \sim 4$ & 2.7 & 0.110 & 77.86 & 73.55 \\
\hline $\mathrm{CH}_{3} \mathrm{~S}(\mathrm{PO})_{3}(\mathrm{BO}) \mathrm{H}$ & 4.1 & 0.099 & 78.38 & 78.68 \\
\hline $\mathrm{CH}_{3} \mathrm{~S}(\mathrm{EO})(\mathrm{PO})_{4} \mathrm{H}$ & 4.9 & 0.099 & 77.81 & 77.16 \\
\hline $\mathrm{C}_{4} \mathrm{H}_{9} \mathrm{~S}(\mathrm{EO})(\mathrm{PO})_{4} \mathrm{H}$ & 3.7 & 0.084 & 76.72 & 72.92 \\
\hline $\mathrm{H}(\mathrm{PO})_{\mathrm{X}} \mathrm{S}(\mathrm{PO})_{\mathrm{Y}} \mathrm{h}, \mathrm{X}+\mathrm{Y} \sim 4$ & 5 & 0.125 & 76.73 & 74.64 \\
\hline $\mathrm{H}(\mathrm{PO})_{\mathrm{X}} \mathrm{S}(\mathrm{PO})_{\mathrm{Y}} \mathrm{h}, \mathrm{X}+\mathrm{Y} \sim 5$ & 4.9 & 0.090 & 77.13 & 73.81 \\
\hline $\mathrm{H}(\mathrm{PO})_{\mathrm{X}} \mathrm{S}(\mathrm{PO})_{\mathrm{Y}} \mathrm{h}, \mathrm{X}+\mathrm{Y} \sim 6$ & 4.7 & 0.092 & 78.61 & 78.39 \\
\hline
\end{tabular}

(EO) : $-\mathrm{CH}_{2} \mathrm{CH}_{2} \mathrm{O}-$, (PO) : - $\mathrm{CH}_{2}\left(\mathrm{CH}_{3}\right) \mathrm{CHO}-,(\mathrm{BO}):-\mathrm{CH}_{2} \mathrm{CH}_{2}\left(\mathrm{CH}_{3}\right) \mathrm{CHO}-$

phlei cells have been used as flotation collectors for hematite $[52,53]$ and as flotation depressants in the anionic flotation of apatite and dolomite [54]. Zheng et al. [55] used Mycobacterium phlei and Bacillus subtilis in order to dolomite depression in anionic flotation. Miettinen et al. [56,57] showed that in anionic flotation of apatite and calcite Staphylococcus carnosus functions as a depressant for apatite, but as an activator for calcite while freeze dried Staphylococcus carnosus can work as a collector for both apatite and calcite. Staphylococcus carnosus and Bacillus firmus were found to work as collectors for apatite [58]. Acidithiobacillus ferrooxidans have been used as cinnabar depressant in cinnabar and antimonite flotation by Lyalikova and Lyubarina [59], and as galena depressant in galena and sphalerite flotation by Rao et al. $[60,61]$. This bacterium has also been used in removing pyrite from mixtures of sulfide minerals [62-65]. Acidithiobacillus ferrooxidans have frequently been used as an excellent pyrite depressant in coal flotation [66-69]. $B a$ cillus polymyxa was used in the separation of sulfide minerals [70], iron ore flotation [71], for pyrite separation from oxide gangue minerals [72], and in the separation of galena from chalcopyrite [73]. Mesquita et al. [74] used Rhodococcus opacus as hematite collector in hematite-quartz flotation. This bacterium was later used as a collector of calcite and magnesite by Botero et al. [75]. Farahat et al. [48] found that Escherichia coli can well work as a collector for quartz.

Two points emerging from these works are:

- All researches have focused on using microorganisms as mineral surface modifiers whereas air phase is as important as solid phase;

- Although there is rather a large body of literature on the direct use of microorganisms in flotation, no attention has been made to the use of microbial products in flotation.

It is well known that some microorganisms are able to produce surface-active compounds that can vary in their chemical structure and size. Since the last decade of the past century the concern about environmental protection has lead to an increased interest in the production and properties of these natural products. These surfactants, often called microbial surfactants or biosurfactants, are considered nowadays as potential substitutes of synthetic chemicals from petrochemical origin. The main advantages of biosurfactants over their chemical counterparts are their lower toxicity, better environmental compatibility, biodegradability, and effectiveness in a wide range of temperatures and $\mathrm{pH}$. Last, but not least, their production by renewable resources provides further impetus for serious consideration of biological surfactants as possible alternatives of the commonly used industrial chemicals. The achievements of the microbial production of biosurfactants and various aspects concerning their potential commercial application regarding bioremediation of soils polluted with heavy metals are well documented and summarized in a number of reviews [76,77].

Among the various species of biosurfactants much work has been done on rhamnose containing microbial surfactants produced by Pseudomonas aeruginosa strains. This ubiquitous environmental bacterium can be isolated from many different habitats including water, soil and plants. These Rhamnolipids produced by $P$. aeruginosa microorganisms are usually as a mixture of two or four species. They differ by the length of hydrophobic chains (from $\mathrm{C}_{8}$ to $\mathrm{C}_{12}$ ) some of which are unsaturated with one double bond. However, under usual growth conditions, two main homologues are primarily obtained: monorhamnolipid (RL-1) and dirhamnolipid (RL-2), as shown in Fig. (19). Numerous articles have considered the process of microbial cultivation of rhamnolipid type biosurfactants on different substrates and their properties in terms of film thickness and wettability.

The first investigation on using these biosurfactants in flotation of coal and minerals was done by Fazaelipoor et al. [79]. They studied frothing characteristics and flotation applicability of rhamnolipid type biosurfactants as frother. These biosurfactants showed better surface-activity and static frothability, i.e. frother height and half-life, in comparison with MIBC. Fig. (20) compares surface tension values from the biosurfactant and MIBC. The results indicate the better ability of the biosurfactant to reduce surface 
tension of water compared to MIBC. The height of froth was measured as a function of aeration rate at two different surfactant concentrations. Fig. (21) shows the results. The biosurfactant produced higher froth heights compared to MIBC.

(a)

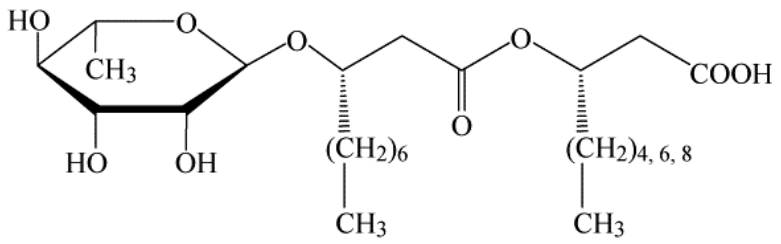

(b)

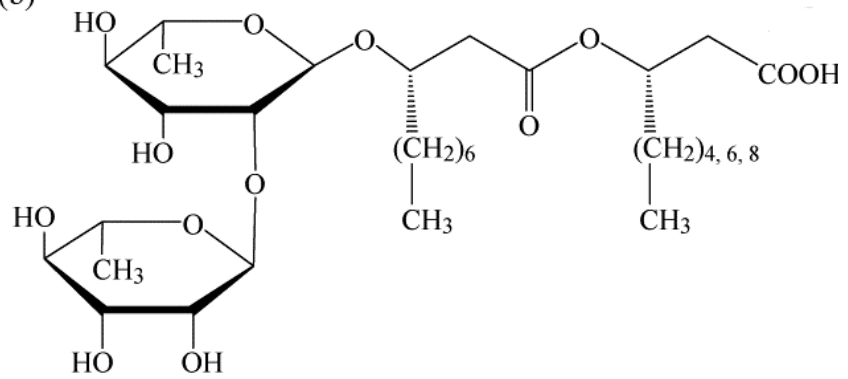

Fig. (19). Monorhamnolipid (RL-1) (a) and dirhamnolipid (RL-2) (b) produced from Pseudomonas aeruginosa bacteria [78].

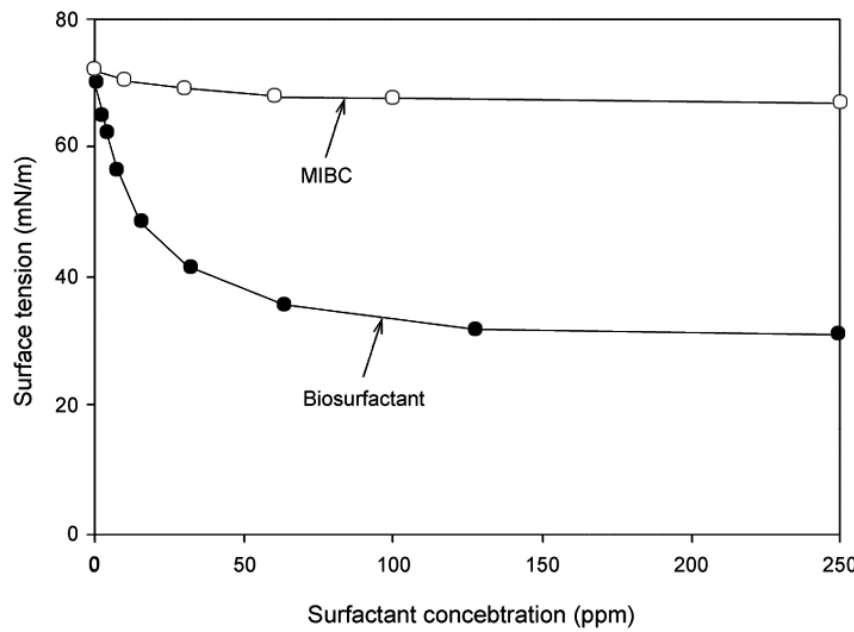

Fig. (20). Comparison of the biosurfactant and MIBC in reducing surface tension of distilled water [79].

There might be two responsible reasons for these results. First, rhamnolipid biosurfactant has a much higher molecular weight ( $>438 \mathrm{~g} / \mathrm{mol}$, depending on the RL-1 and RL-2 ratio) compared to MIBC and this higher molecular weight leads to a more viscous, and hence more stable, froth layer. Second, there is only one $-\mathrm{OH}$ group in MIBC and this group will interact with water molecules to form an oriented monolayer at the surface; but in biosurfactant, there are several oxygenated units in the molecular chain and each unit can interact with water molecules through hydrogen bonding, causing the molecules to tend to lie flat at the surface, possibly increasing the viscosity of the froth.
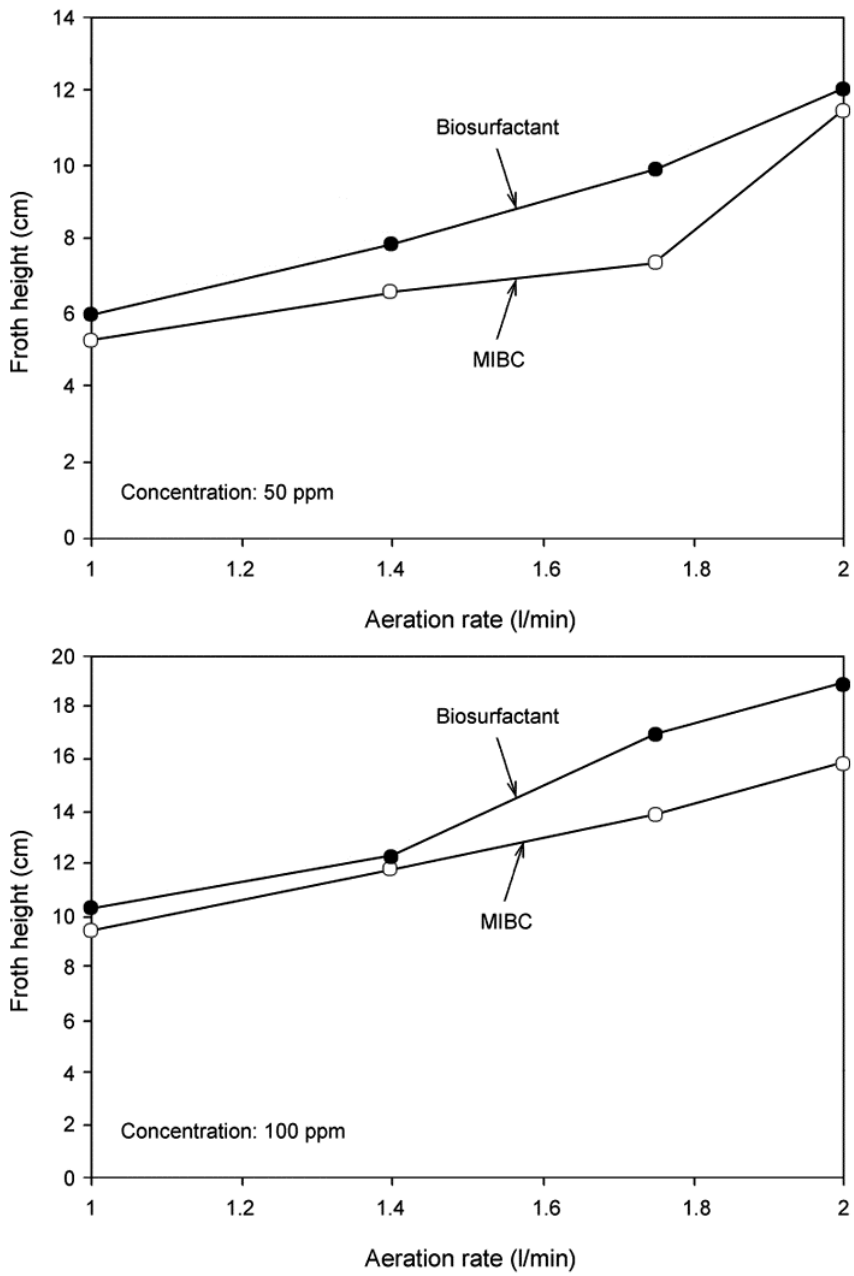

Fig. (21). Froth height as a function of aeration rate [79].

Fig. (22) shows the froth half-life values for both surfactants. The results indicate that at the lower concentration MIBC produces more stable froth, while at higher concentration the reverse is true. It seems that at lower concentration the interfacial adsorption density of biosurfactant is less than MIBC due to greater structural and atomic dimensions. At higher concentration the adsorption density of biosurfactant increases by multi-layer adsorption mechanism because of free oxygen and multiple $-\mathrm{OH}$ groups.

Coal flotation tests using rhamnolipid biosurfactants as the sole frother of the process yielded products of 72-79 percent recovery with 10-15.5 percent ash content supporting 55-57.5 percent efficiency. These results seem to be promising to introduce rhamnolipid type biosurfactants as a new "biofrother". Rhamnolipids are commercially available from Jeneil Biosurfactant Company, Saukville, Wisconsin, USA, and Urumqi Unite Bio-Technology Co., Ltd., China.

\section{SUMMARY}

The literature review presented in this article tried to prepare an updated, comprehensive database of frothers regarding to their classifications, properties, and a brief description of their preparation methods. As a summary, the following general remarks can be denoted: 

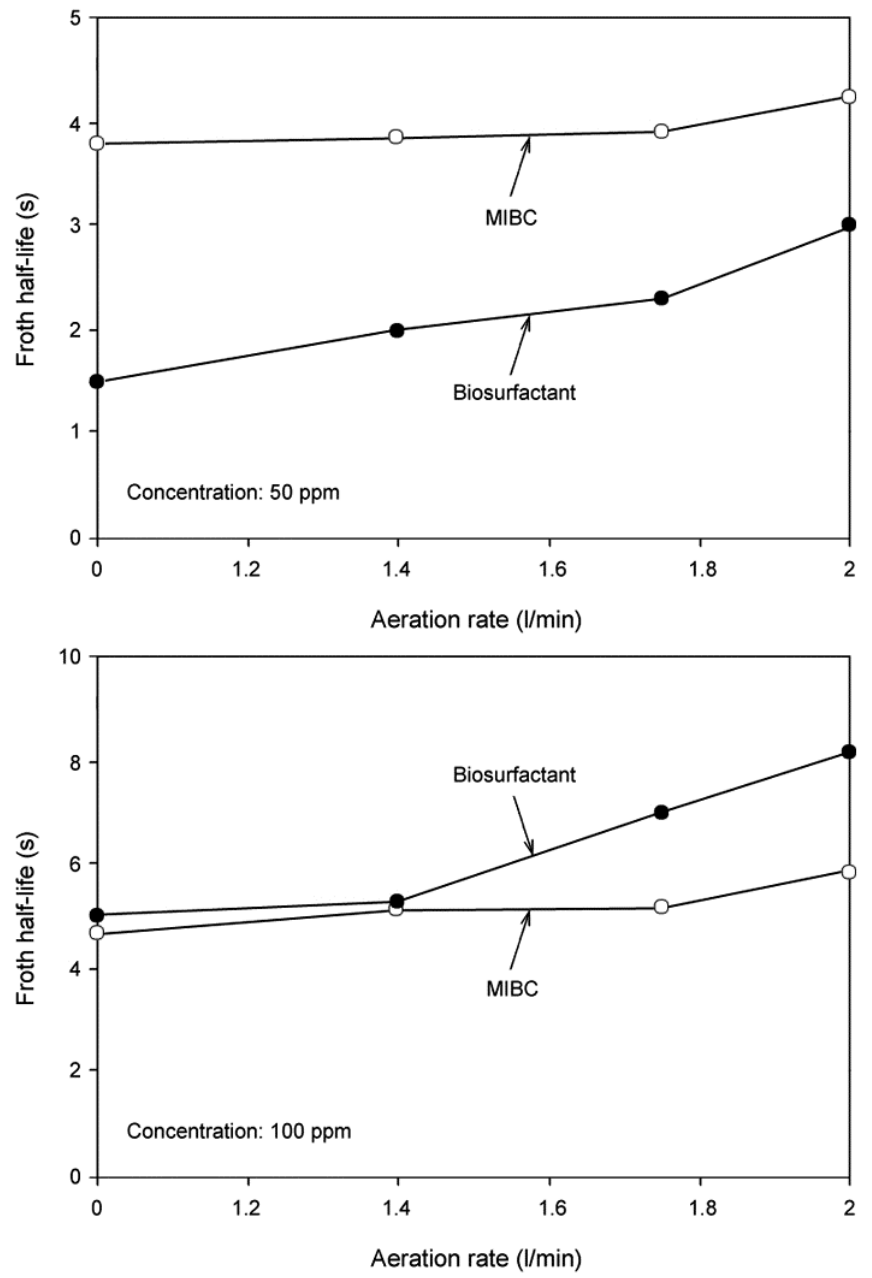

Fig. (22). Froth half-life as a function of aeration rate [79].

- Neutral frothers, specially aliphatic alcohol and ether types, are the most important group of frothers widely used in flotation of base-metal ores, oxidic minerals and industrial minerals, since they are functional in both acidic and alkaline pulps.

- From the practical point of view, the most important characteristics of frothers are molecular weight $(\mathrm{Mw})$, hydrophile-lipophile balance (HLB), dynamic frothability index (DFI), and critical coalescence concentration (CCC). Available data on these parameters were listed in Table 8, having yet some blank cells which necessitate more researches in this regard.

- Considering selectivity/frothing-power based classification, different mixed frother systems, usually mixtures of aliphatic alcohol and ether frothers are used to support an efficient flotation operation, a wide size distributed feed.

- Different new classes of frothers discussed in this review are actually conventional frothers modified by incorporating certain functional group, specially polyalkoxylated molecules, or atoms into their molecular structure.

- Like particle surface modifiers, frothers are also influenced by biotechnology, leading to introduce a new class of biological frothers, i.e. biosurfactants, so called as "biofrother". A comprehensive research program is being investigated by the authors to characterize frothing properties and coal and ores flotation applicability of such a biofrother.

\section{ACKNOWLEDEMENT}

The authors thank the support from Sarcheshmeh Copper Complex, Kerman, Iran for their keen interest in carrying out this study. The following people are also gratefully acknowledged for their help in providing some useful information during the preparation of this manuscript: Prof. Janusz S. Laskowski of Department of Mining Engineering, University of British Columbia, Vancouver, Canada; Prof. Jan Cilliers of Royal School of Mines, Imperial College, London, UK; Prof. Zongming Rong of Department of Chemistry, East China University of Science and Technology, Shanghai, People's Republic of China; Prof. Paula V. Messina of Departamento de Química, Universidad Nacional del Sur, Argentina; and Ms. K.E. Cole (PhD. Student) of Department of Earth Science and Engineering, South Kensington Campus, Imperial College London, UK.

\section{REFERENCES}

[1] S.A. Wrobel, "Flotation frothers: their action, properties and structures," In: Recent Developments in Mineral Processing, C.W. Dannat, Ed. London: The Institution of Mining and Metallurgy, 1953, pp. 431-450.

[2] J. Leja, Surface Chemistry of Froth Flotation. Plenum Press: New York, 1982.

[3] J.A. Kitchener, and C.F. Cooper, "Current concepts in the theory of foaming", Q. Rev., vol. 13, pp. 71-97, 1959.

[4] R.J. Pugh, "Experimental techniques for studying the structure of foams and froths", Adv. Colloid Interface Sci., vol. 114-115, pp. 239-251, 2005.

[5] S.R. Rao, Surface Chemistry of Froth Flotation. vol. 1, 2nd ed. Kluwer Academic/Plenum Publishers: New York, 2004.

[6] B.A. Comley, P.J. Harris, D.J. Bradshaw, and M.C. Harris, "Frother characterization using dynamic surface tension measurements", Int. J. Miner. Process., vol. 64, pp. 81-100, 2002.

[7] S.M. Bulatovic, Handbook of Flotation Reagents (Chemistry, Theory and Practice: Flotation of Sulfide Ores), vol. 1, Elsevier Science \& Technology Books: Amsterdam, 2007.

[8] J.S. Laskowski ed. Frothing in Flotation, Gordon and Breach Science Publishers, 1989.

[9] E.T. Woodburn ed. Frothing in Flotation II, Taylor and Francis Publisher, 1998.

[10] Sam, "Single bubble behavior study in a flotation column", Ph.D thesis, McGill University, Montreal, Canada, 1995.

[11] S.V. Dudenkov, and A.A. Galikov, Theory and Practice of Application of Flotation Reagents. Nedra: Russia, 1969.

[12] Wikipedia Free Encyclopedia, 2010. [Online] Available: www.wikipedia.com. [Accessed 2010].

[13] G. Collin, H. Höke, and H. Greim, "Naphthalene and hydronaphthalenes," In: Ullmann's Encyclopedia of Industrial Chemistry, Vol. 22, 6th Ed. Germany: Wiley-VCH Verlag GmbH \& Co., 2002, pp. 399-409.

[14] R.D. Crozier, Flotation: Theory, Reagents and Ore Testing. Pergamon Press: London, 1992.

[15] J.S. Laskowski, Coal Flotation and Fine Coal Utilization. Elsevier Science \& Technology Books: Amsterdam, 2001.

[16] J. Falbe, H. Bahrmann, W. Lipps, and M. Dieter, "Alcohols, aliphatic," In: Ullmann's Encyclopedia of Industrial Chemistry, Vol. 2, 6th Ed. Germany: Wiley-VCH Verlag GmbH \& Co., 2002, pp. 19-47.

[17] COM124, "Diacetone Alcohol", Material Safety Data Sheet, Comet Chemical Company Ltd., 2008. [Online] Available: www. cometchemical.com. [Accessed 2010].

[18] ICSC:1030, "n-Octanol", International Occupational Safety and Health Information Centre (CIS), 2002. [Online] Available: www.ilo.org. [Accessed 2010]. 
[19] ICSC:0629, "TEXANOL", International Occupational Safety and Health Information Centre (CIS), 2003. [Online] Available: www.ilo.org. [Accessed 2010].

[20] E. Gildemeister, The Volatile Oils, vol. 1, 2nd ed. John Wiley and Sons Publication: New York, 1913.

[21] FAO, "Piperitone", Food and Agriculture Organization of the United Nations, 2009. [Online] Available: www.fao.org. [Accessed 2010].

[22] GSC, "Alpha-fenchol", The Good Scents Company Information, 2009. [Online] Available: www.thegoodscentscompany.com. [Accessed 2010].

[23] E.C. Tveter, "Frothers for the flotation of sulfide ores," US Pat. $2,611,485,1952$.

[24] R.B. Booth, "Frothing agents for the flotation of ores and coal," US Pat. 2,675,101, 1954.

[25] R.B. Booth, "Frothing agents for the flotation of ores and coal," US Pat. 3,595,390, 1971.

[26] R.B. Booth, and J.M. Dobson, "Frothing agents for the flotation of ores and coal," US Pat. 2,695,101, 1954.

[27] G.H. Harris, and R. Jia, "An improved class of flotation frothers", Int. J. Miner. Process., vol. 58, pp. 35-43, 2000.

[28] J.J. Hostynek, and D.J. Collins, "Frothing agents for the flotation of ores," US Pat. 3,710,939, 1973.

[29] S.N. Tan, R.J. Pugh, D. Fornasiero, R. Sedev, and J. Ralston, "Foaming of polypropylene glycols and glycol/MIBC mixtures", Miner. Eng., vol. 18, pp. 179-188, 2005.

[30] J.R. Hernandez-Aguilar, R. Cunningham, and J.A. Finch, "A test of the Tale equation to predict bubble size at an orifice in the presence of frother", Int. J. Miner. Process., vol. 79, pp. 89-97, 2006.

[31] S.N. Tan, D. Fornasiero, R. Sedev, and J. Ralston, "The interfacial conformation of polypropylene glycols", Colloids Surf. A, vol. 250, pp. 307-315, 2004.

[32] J.S. Laskowski, "Testing flotation frothers", Physicochem. Prob. Miner. Process., vol. 38, pp. 13-22, 2004.

[33] V.I. Klassen, and V.A. Mokrousov, An Introduction to the Theory of Flotation. Butterworth: London, 1963.

[34] R.R. Klimpel, and R.D. Hansen, "Frothers," In: Reagents in Mineral Technology. P. Somasundaran, and B.M. Moudgil, Ed. New York: Marcel Dekker Inc., 1988, pp. 385-411.

[35] J.S. Laskowski, "Fundamental properties of flotation frothers", In: Twenty Second International Mineral Processing Congress, 2003, pp. 788-797.

[36] F. Melo, and J.S. Laskowski, "Fundamental properties of flotation frothers and their effect on flotation", Int. J. Miner. Process., vol. 19, pp. 766-773, 2006.

[37] A.K. Gupta, P.K. Banerjee, A. Mishra, and P. Satish, "Influence of chemical parameters on selectivity and recovery of fine coal through flotation", Int. J. Miner. Process., vol. 92, pp. 1-6, 2009.

[38] J.S. Laskowski, T. Tlhone, P. Williams, and K. Ding, "Fundamental properties of polyoxypropylene alkyl ether flotation frothers", Int. J. Miner. Process., vol. 72, pp. 289-299, 2003.

[39] Y.S. Cho, and J.S. Laskowski, "Effect of flotation frothers on bubble size and foam stability", Int. J. Miner. Process., vol. 64, pp. 6980, 2002.

[40] L. Wang, and R-H. Yoon, "Effects of surface forces and film elasticity on foam stability", Int. J. Miner. Process., vol. 85, pp. 101$110,2008$.

[41] A.K. Gupta, P.K. Banerjee, A. Mishra, P. Satish, and Pradip, "Effect of alcohol and polyglycol ether frothers on foam stability, bubble size and coal flotation", Int. J. Miner. Process., vol. 82, pp. 126-137, 2007.

[42] R.J. Pugh, "Non-ionic polyethylene oxide frothers in graphite flotation", Miner. Eng., vol. 13, pp. 151-162, 2000.

[43] R.O. Keys, "Modified alcohol frothers for froth flotation of sulfide ore," US Pat. 4,678,563, 1987.

[44] M. Biermann, R. Koester, and H. Eierdanz, "Use of derivatives of tricyclo-(5.2.1.1.6.6 -dec-3-ene as frothers in the flotation of coal and ores," US Pat. 4,925,559, 1990.

[45] R.R. Klimpel, and S. Isherwood, "Some industrial implication of changing frother chemical structure", Int. J. Miner. Process., vol. 33, pp. 369-381, 1991.

[46] K. Rasheed, "Aromatic and aliphatic sulfonates and properties and applications thereof," US Pat. 5,919,975, 1999.

[47] F. Cappuccitti, and J.A. Finch, "Development of new frothers through hydrodynamic characterization", Miner. Eng., vol. 21, pp. 944-948, 2008.
[48] M. Farahat, T. Hirajima, K. Sasaki, Y. Aiba, and K. Doi, "Adsorption of SIP E. coli onto quartz and its applications in froth flotation", Miner. Eng., vol. 21, pp. 389-395, 2008.

[49] T.R. Hosseini, "Feasibility study of bioflotation of Sarcheshmeh sulfide copper ore", M.S. thesis, Tehran University, Tehran, Iran, 2003.

[50] P.M. Solozhenkin, and L.L. Lyubavina, "Modern aspects of microbiological hydrometallurgy," In: Modern Aspects of Microbiological Hydrometallurgy, G.I. Karavaiko, and S.N. Groudev, Ed. Moscow: Center for International Projects, 1985, pp. 409-414.

[51] J.E. Zajic, and N. Kosaric, "Flotation of scheelite from calcite with a microbial based collector," US Pat. 4,046,678, 1977.

[52] M. Misra, and R.W. Smith, "Bioflocculation of minerals," In: Mineral Bioprocessing. R.W. Smith, and M. Misra, Ed. Berlin: Springer, 1991, pp. 91-104.

[53] J. Dubel, R.W. Smith, M. Misra, and S. Chen, "Microorganisms as chemical reagents: the hematite system", Miner. Eng., vol. 5, pp. 547-556, 1992.

[54] X. Zheng, and R.W. Smith, "Dolomite depressants in the flotation of apatite and collophane from dolomite", Miner. Eng., vol. 10, pp. 537-545, 1997.

[55] X. Zheng, P.J. Arps, and R.W. Smith, "Adhesion of two bacteria onto dolomite and apatite: their effect on dolomite depression in anionic flotation", Int. J. Miner. Process., vol. 62, pp. 159-172, 2001.

[56] R. Miettinen, M. Ratto, J. Leppinen, and R.W. Smith, "Biobeneficiation with bacteria", Internal report, Finland, VTT, Outokumpu, 2003.

[57] R. Miettinen, M. Ratto, J. Leppinen, and R.W. Smith, "Flocculation of apatite, calcite and quartz using bacteria", Internal report. Finland, VTT, Outokumpu, 2003.

[58] R.W. Smith, and M. Mittinen, "Microorganisms in flotation and flocculation: future technology or laboratory curiosity?", Miner. Eng., vol. 19, pp. 548-553, 2006.

[59] N.N. Lyalikova, and L.L. Lyubavina, "On the possibility of using a culture of Thiobacillus Ferrooxidans to separate antimony and mercuric sulfides during flotation," In: Fundamentals and Applications of Biohydrometallurgy, R.W. Lawrence, R.M.R. Branion, and H.G Ebner, Ed. New York: Elsevier, 1986, pp. 403-406.

[60] M.K.Y. Rao, K.A. Natarajan, and P. Somasundaran, "Effect of bacterial conditioning of sphalerite and galena with Thiobacillus ferrooxidans on their floatability," In: Mineral Bioprocessing, R.W. Smith, and M. Misra, Ed. Berlin: Springer, 1991, pp. 105-120.

[61] M.K.Y. Rao, K.A. Natarajan, and P. Somasundaran, "Effect of biotreatment with Thiobacillus ferrooxidans on the floatability of sphalerite and galena", Miner. Metal. Process., vol. 9, pp. 95-100, 1992.

[62] T. Nagaoka, N. Ohmura, and H. Saiki, "A novel mineral flotation process using Thiobacillus ferrooxidans", Appl. Environ. Microbiol., vol. 9, pp. 3588-3593, 1999.

[63] D. Santhiya, S. Subramanian, K.A. Natarajan, K.H. Rao, K. Hanumantha, and K.S.E. Forssberg, "Bio-modulation of galena and sphalerite surfaces using Thiobacillus thiooxidans", Int. J. Miner. Process., vol. 62, pp. 121-141, 2001.

[64] T.R. Hosseini, M. Kolahdoozan, Y.S.M. Tabatabaei, M. Oliazedeh, M. Noaparast, A. Eslami, Z. Manafi, and A. Alfantazi, "Bioflotation of Sarcheshmeh copper ore using Thiobacillus ferrooxidans bacteria", Miner. Eng., vol. 18, pp. 371-374, 2005

[65] A.E. Yüce, H.M. Tarkan, and M.Z. Dogan, "Effect of bacterial conditioning and the flotation of copper ore and concentrate", Afr. J. Biotechnol., vol. 5, pp. 448-452, 2006.

[66] A.S. Atkins, C.C. Townsley, and S.I. Al-Ameen, "Application of a biological sulphur depressant to the desulphurization of coal in froth flotation", In: Conference of Minerals Preparation'87, 1987, pp. 5-21.

[67] M. El Zeky, and Y.A. Attia, "Coal slurries desulfurization by flotation using Thiophilic bacteria for pyrite depression", Coal Prep., vol. 5, pp. 15-37, 1987.

[68] Y.A. Attia, M. El Zeky, and M. Ismail, "Enhanced separation of pyrite from oxidized coal by froth flotation using surface modification", Int. J. Miner. Process., vol. 37, pp. 61-71, 1993.

[69] M. Misra, K. Bukka, and S. Chen, "The effects of growth medium of Thiobacillus ferrooxidns on pyrite flotation", Miner. Eng., vol. 9, pp. $157-168,1996$

[70] P.K. Sharma, K.H. Rao, K.S.E. Forssberg, and K.A. Natarajan, "Surface chemical characterization of Paenibacillus polymyxa be- 
fore and after adaptation to sulfide minerals", Int. J. Miner. Process., vol. 62, pp. 3-25, 2001.

[71] K.A. Natarajan, and N. Deo, "Role of bacterial interaction and bioreagents in iron ore flotation", Int. J. Miner. Process., vol. 62, pp. 143-157, 2001.

[72] P. Patra, and K.A. Natarajan, "Microbially-induced flocculation and flotation for pyrite separation from oxide gangue minerals", Miner. Eng., vol. 16, pp. 965-973, 2003.

[73] P. Patra, and K.A. Natarajan, "Microbially-induced separation of chalcopyrite and galena", Miner. Eng., vol. 21, pp. 691-698, 2008.

[74] L.M.S. Mesquita, F.F. Lins, and M.L. Torem, "Interaction of a hydrophobic bacterium strain in a hematite-quartz flotation system", Int. J. Miner. Process., vol. 71, pp. 31-44, 2003.

[75] A.E.C. Botero, M.L. Torem, and L.M.S. Mesquita, "Fundamental studies of Rhodococcus opacus as a biocollector of calcite and magnesite", Miner. Eng., vol. 20, pp. 1026-1032, 2007.
[76] R. Cohen, and D. Exerowa, "Surface forces and properties of foam films from rhamnolipid biosurfactants", Adv. Colloid Interface Sci., vol. 134-135, pp. 24-34, 2007.

[77] Vilinska, K.H. Rao, and K.S.E. Forssberg, "Microorganisms in flotation and flocculation of minerals-an overview," In: twenty Forth International Mineral Processing Congress, 2008, pp. 22-39.

[78] N.P.J. Price, K.J. Ray, K. Vermillion, and T-M. Kuo, "MALDITOF mass spectrometry of naturally occurring mixtures of monorhamnolipids and dirhamnolipids", Carbohydr. Res., vol. 344, pp. 204-209, 2009.

[79] M.H. Fazaelipoor, H. Khoshdast, and M. Ranjbar, "Coal flotation using a biosurfactant from Pseudomonas aeruginosa as a frother", Korean J. Chem. Eng., vol. 27, pp. 1527-1531, 2009.

(C) Khoshdast and Sam; Licensee Bentham Open.

This is an open access article licensed under the terms of the Creative Commons Attribution Non-Commercial License (http://creativecommons.org/licenses/ by-nc/3.0/) which permits unrestricted, non-commercial use, distribution and reproduction in any medium, provided the work is properly cited. 